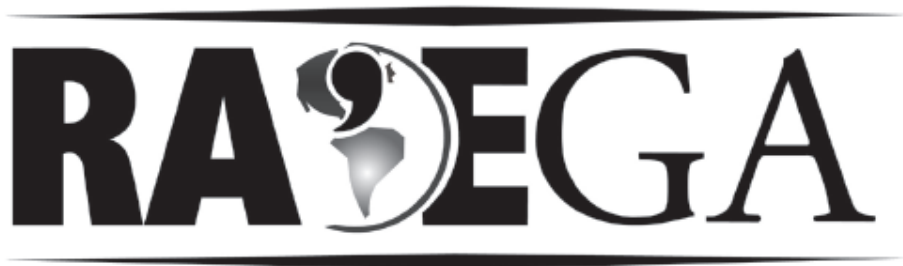

O ESPAÇO GEOGRÁFICO EM ANÁLISE

\title{
INTERAÇÕES ENTRE A CARSTOLOGIA E A GEOGRAFIA CULTURAL
}

\section{Interactions between Karstology and Cultural Geography}

\author{
Luiz Eduardo Panisset Travassos ${ }^{1}$
}

\section{RESUMO}

A paisagem cárstica e suas cavernas podem ser percebidas por várias pessoas de maneira igualmente variada. Do leigo ao cientista, especialmente as cavernas, assumem significados diversos de acordo com a evolução histórica e as condições culturais de uma sociedade. Por esse motivo, é possível afirmar que a relação humana com as cavernas não é fato novo na história da humanidade. Muito menos a motivação para seu uso como abrigos, esconderijos ou lugares sagrados. Sendo assim, as cavernas e o carste constituem-se como importantes registros histórico-geográficos de regiões específicas. Muitas vezes apresentam traços comuns a várias culturas como será demonstrado ao longo do trabalho. Como objetivo geral do trabalho, propõe-se a investigação do uso cultural do carste e das cavernas como base do Turismo Cultural. Sendo assim, busca-se realizar um estudo que favoreça a divulgação do uso cultural do carste e das cavernas a fim de colaborar com as discussões sobre o uso religioso de cavernas e inserir a temática nos estudos de Geografia da Religião em particular, e da Geografia Cultural em geral.

Palavras-chave: Carste, Cavernas, Geografia Cultural, Geografia da Religião.

\footnotetext{
1 Doutor em Geografia. Professor do Programa de Pós-Graduação em Geografia - Tratamento da Informação Espacial. Pontifícia Universidade Católica de Minas Gerais luizpanisset@uol.com.br / luizepanisset@gmail.com
} 


\section{ABSTRACT}

The karst landscape and the caves can be perceived by several people in an equally varied way. From the layman to the scientist, especially caves, assume different meanings according to historical and cultural conditions of a particular society. Therefore, we one can say that the human relationship with caves is not really new in the history of mankind. It is also not less new the motivation for their use as shelters, safe houses and sacred places. Thus, caves and karst are important historical and geographic records of specific regions. Often they present common features of various cultures as shown throughout this work. As a general objective of this research, it is proposed the investigation of the cultural use of karst and caves based on the Cultural Tourism. The objective is to undertake a study that helps to promote the dissemination of the cultural use of karst and caves as well contribute to the discussions on the religious use of caves and insert this topic in the studies of the geography of religion in particular and of the Cultural Geography in general.

Keywords: Karst, Caves, Cultural Geography, Geography of Religion.

\section{INTRODUÇÃO}

A paisagem cárstica e suas cavernas podem ser percebidas por várias pessoas de maneira igualmente variada. Do leigo ao cientista, especialmente as cavernas, assumem significados diversos de acordo com a evolução histórica e as condições culturais de uma sociedade.

As regiões desenvolvidas em rochas carbonáticas como 0 calcário, perfazem cerca de 10 a 15\% da superfície terrestre (FORD; WILLIAMS, 2007) e Williams (2008) afirma que o carste é encontrado, principalmente, em rochas mais solúveis como o calcário, o mármore e o dolomito. Entretanto, afirma que tal tipo de paisagem pode desenvolver-se também em evaporitos.

Sendo assim, os afloramentos carbonáticos compreendem cerca de $15.000 .000 \mathrm{~km}^{2}$ da área continental não congelada da Terra (11\% da superfície). Já os carbonatos subsuperficiais envolvidos na circulação da água subterrânea são consideravelmente maiores: cerca de $14 \%$ da área mundial (WILLIAMS, 2008).

Dessa forma, uma nova proposição dessas porcentagens, especialmente no tocante aos afloramentos rochosos, foi realizada por Williams 
e Fong (2008). Nesta nova proposta, os autores demonstram que cerca de 12,5\% da superfície terrestre mundial apresentam afloramentos carbonáticos. Os autores destacam que se propõem a diferenciar as áreas onde as rochas carbonáticas são relativamente puras e contínuas daquelas relativamente impuras e descontínuas (Figura 1).

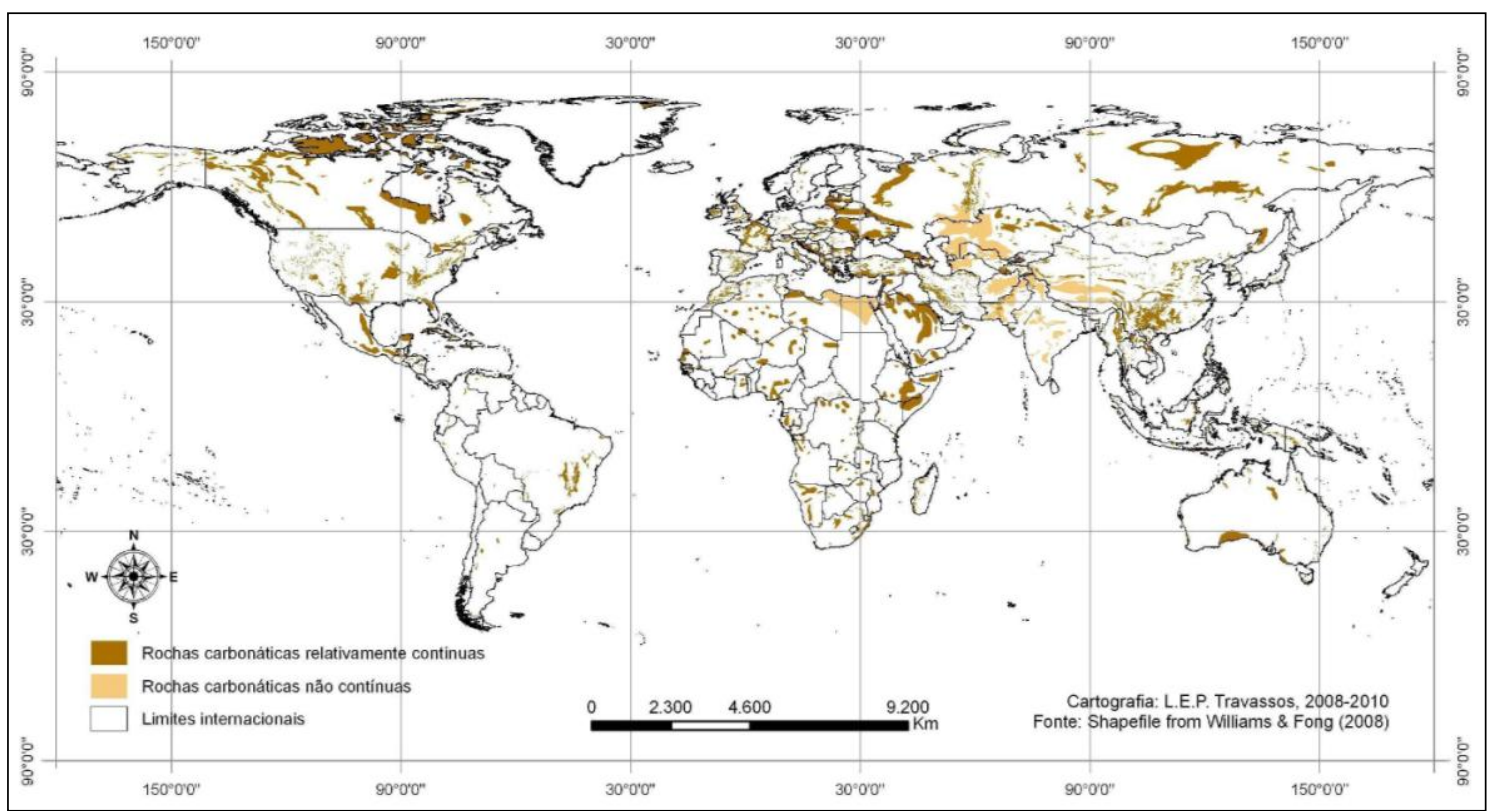

Figura 1 - Distribuição espacial das rochas carbonáticas de acordo com Williams e Fong (2008). As áreas escuras correspondem a regiões carbonáticas relativamente contínuas. As áreas de cor mais clara correspondem a regiões abundantes em rochas carbonáticas não contínuas.

É possível considerar que todas as rochas são solúveis em algum grau e, por isso, feições de dissolução de micro escala podem ser encontradas em "rochas insolúveis" como o quartzito e o basalto. Embora tenham feições cársticas, pois são formadas inteiramente pela dissolução, a paisagem da qual fazem parte não é cárstica, pois é formada por rochas relativamente insolúveis e dominada por feições produzidas por outros processos naturais (WILLIAMS, 2008).

Como demonstrado na Figura 1 é possível observar o quão distribuído é o carste ao longo da superfície terrestre. Sendo assim, não é de se estranhar o fato de que estas regiões tenham sido utilizadas pelo homem primitivo desde os seus primórdios. Pela própria característica do relevo, eram lugares ideais para serem utilizados como abrigo e fonte de recursos naturais. 
Nas regiões cársticas, estabeleceram-se os primeiros assentamentos humanos. Por todo o mundo é possível observar que populações inteiras são abastecidas por mananciais cársticos e, em várias culturas, as cavernas ainda são utilizadas como locais para a prática de rituais religiosos (como manifestações culturais), além de outras formas de uso (TRAVASSOS, 2007d).

O estudo deste tipo peculiar de relevo já podia ser observado em trabalhos de filósofos gregos e romanos conforme destacado por Travassos (2007d) e mais recentemente por Clendenon (2009a; 2009b). Breves descrições do Carste Clássico (localizado na região do Planalto de Kras, na Eslovênia) já apareciam em obras do século IV a.C., bem como em trabalhos de Estrabão, Plínio, Políbio, entre outros. Em uma descrição clara de um sumidouro e de uma ressurgência, Posidônio de Apameia (135-50 a.C.) afirma que o rio Timavus sumia entre as montanhas, fluindo em um abismo e somente reaparecia a uma distância de 130 estádios (41,25 metros.), em direção ao mar (KRANJC, 1997; KRANJC, 2006a; TRAVASSOS; KOHLER; KRANJC, 2006).

Para Kranjc (2006b), o geógrafo romano Estrabão (63 a.C - 21 d.C.) foi provavelmente o primeiro a mencionar o Lago de Cerknica (na Eslovênia) e Clendenon (2009a) lembra que Aristóteles foi, provavelmente, o primeiro a descrever e deduzir corretamente o comportamento das águas cársticas na obra Meteorologia em 350 a.C.

Para Travassos, Kohler e Kranjc (2006) a Tábula de Peutinger , elaborada na Idade Média, já mostrava indícios de assentamentos humanos no carste. Os mesmos autores ainda afirmam que uma espécie de turismo cultural teria surgido na região do Planalto de Kras (ainda que de forma primitiva) na Sveta Jama (Caverna Sagrada), em 280 d.C e na Landarska Jama (Caverna de Landar) por volta de 888 d.C. Inúmeros viajantes passam, também, a ser atraídos pelas belezas naturais da Postojska Jama (Caverna de Postojna) em 1213 d.C e da Vilenica Jama (Caverna Vilenica) em 1663.

De acordo com Kranjc (1997, 2006a) e Travassos, Kohler e Kranjc (2006), já no final do século XVII e início do século XVIII, a região do Planalto de Kras torna-se ainda mais popular pela descrição de geógrafos, topógrafos, viajantes e outros estudiosos. Essa popularização ocorreu, em grande parte 
também, pelo fato de Trieste (Itália) ter se transformado em um porto de livre comércio em 1719.

A importância da região para a Carstologia quando afirmam que diversos pesquisadores pioneiros começaram a se dedicar ainda mais ao estudo da região de Kras. São eles J.V. Valvasor (1689), Nagel (1748), B. Hacquet (17781789) e F. J. H. Hohenwart (1830). Na obra de Franc Jožef Hanibal Hohenwart (1830) aparece, pela primeira vez, o termo "karstes". Geógrafos e geólogos do século XIX passam a utilizar com mais freqüência o termo karst e o trabalho de Jovan Cvijić (1893) fornece a base científica ao estudo do Carste Clássico, seguido por Kraus (1894) e Martel (1894), por exemplo (KRANJC, 1997; KRANJC, 2006a; TRAVASSOS; KOHLER; KRANJC, 2006).

Como é possível perceber pelo breve histórico anterior, a forma germânica "karst" originou-se na região do Planalto de Kras, na Eslovênia. Para Kranjc (2001), sua origem pré-indo-europeia possui a raiz kar/gar ou kara/gara, significando rocha ou rochoso, respectivamente. O termo kras é amplamente utilizado na Eslovênia para designar regiões rochosas ou não favoráveis à agropecuária, sendo aplicado para identificar algumas regiões do Carste Dinárico caracterizado por campos de lapiás e dolinas.

Gillieson (1996) afirma que esse tipo peculiar de paisagem é também comumente caracterizado por possuir depressões fechadas, drenagem subterrânea e cavernas formadas, principalmente, pela dissolução da rocha. Para Sweeting (1972) e Ford (2007), o termo germânico (karst) foi popularizado pela obra Das karstphenömen de Cvijić (1893) e é utilizado como padrão mundial, designando processos de dissolução da rocha e sistemas subterrâneos derivados desse processo.

Outra corrente científica tem buscado a utilização do termo carste para paisagens desenvolvidas em outros tipos de rochas que não sejam as carbonáticas. Entretanto, acredita-se que a utilização do termo pseudocarste seja mais apropriada. Isso ocorre, pois rochas siliciclásticas ou silicosas são passíveis de desenvolver formas características similares ao "carste clássico" (e.g.: dolinas, drenagem subterrânea e cavernas). Estas possuem sua gênese por diferentes processos uma vez que, em tais áreas, a dissolução da rocha 
ocorre de forma subordinada a processos mecânicos. No Brasil, exemplos podem ser encontrados em quartzitos e arenitos.

No presente trabalho, os fenômenos cársticos, que são condicionados por processos hidrogeoquímicos específicos através da água rica em $\mathrm{CO}_{2} \mathrm{e}$ naturalmente acidulada, serão abordados no âmbito Histórico e Cultural. 0 fascinante cenário superficial e subterrâneo será estudado além de sua abordagem puramente física.

Destaca-se que, quando é chamada a atenção ao problema do uso sustentável do carste, a vertente cultural e humanística é por vezes esquecida. Além da preservação de seus recursos físicos, devemos atentar para seu lado cultural, igualmente importante. Entender a forma como um grupo social percebe o carste pode ser, muitas vezes, o caminho para sua preservação.

Ravbar (2007), ao dedicar uma importante obra à proteção das águas cársticas, escolheu uma epígrafe para iniciar seu trabalho que destaca a importância primária do carste: "Nunca cuspa em um poço, você poderá ter que beber dele depois" (BASIN; KRYLOV; IVAN ANDREJEVIČ, 1809). Uma frase simples que traduz o que Humboldt já afirmava: tudo está interligado, de acordo com o clássico princípio geográfico da conexão.

\section{AS ÁREAS CÁRSTICAS BRASILEIRAS}

Com exceção das bacias sedimentares terciárias do pantanal matogrossense, da Amazônia e de trechos do litoral, o território brasileiro desenvolve-se sobre estruturas geológicas antigas. Suas idades variam do Paleozoico ao Mesozoico para bacias meta-sedimentares, e do Pré-Cambriano (Arqueano/Proterozoico) para os terrenos cristalinos da Plataforma SulAmericana. Entre esses, destacam-se as áreas cratônicas, os cinturões de dobramentos antigos e as bacias sedimentares (SCHOBBENHAUS; BRITO NEVES, 2003).

Da área continental brasileira de 8,5 milhões de $\mathrm{km}^{2}$, Karmann (1994) estimou que cerca de 5 a $7 \%$ são constituídos por terrenos cársticos. Entretanto, Auler (2002) afirma que cerca 2,2 \% do território brasileiro 
apresenta carbonatos aflorantes e Karmann e Sallun Filho (2007) afirmam que o total seria de 2,8\%. De maneira geral, tais áreas devem ser consideradas as principais unidades geológicas favoráveis ao desenvolvimento de feições cársticas. As principais unidades localizam-se no Cráton São Francisco, na região de Minas Gerais, Goiás e Bahia, sobre litologias carbonáticas e dolomíticas do Proterozóico Superior.

Roldan, Wahnfried e Klein (2003) afirmam que as principais províncias espeleológicas nacionais seriam a Província Espeleológica Vale do Ribeira (localizada no sul do Estado de São Paulo e oeste do Estado do Paraná), a Província Espeleológica do Bambuí (engloba porções SE do Tocantins, centro leste e SE de Goiás, centro oeste e NW de Minas Gerais e W da Bahia), a Província Espeleológica Uná, e a Província Espeleológica da Serra da Bodoquena (a maior região carbonática do Mato Grosso do Sul, se estendendo por cerca de $200 \mathrm{~km}$ na direção N-S, no sudoeste do Estado). Com o aumento das pesquisas sobre as regiões cársticas brasileiras, os trabalhos de Auler, Rubbioli e Brandi (2001) e Auler (2002), afirmam que existem 14 importantes províncias carbonáticas, além das ocorrências menos significativas.

Em relação a esse cenário nacional, o estado de Minas Gerais destacase por apresentar importantes ocorrências de carbonatos e, consequentemente, expressivas áreas cársticas a ela associadas. Para Piló (1997, 1998, 1999), da extensão nacional de aproximadamente 5 a 7\%, cabem ao Estado mineiro cerca de 3 a $5 \%$, ou 17.600 a $29.419 \mathrm{~km}^{2}$.

\section{A RELAÇÃO HUMANA COM AS CAVERNAS}

Pelo exposto, pode-se afirmar que a relação humana com as cavernas não é fato novo na história da humanidade. Muito menos a motivação para seu uso como abrigos, esconderijos ou lugares sagrados. Junto com as montanhas, muitas cavernas tornaram-se importantes pontos para a mitologia, para a criação de lendas, mitos e para as religiões.

Sobre as montanhas consideradas sagradas, Brito (2008) afirma que devido ao contexto predominantemente cristão em que vivemos no Ocidente, 
um fator que contribui para a formação de sua concepção sagrada ("coisas de Deus") ocorre uma vez que inúmeras passagens e figuras bíblicas fazem referência a esses maciços rochosos.

O mesmo ocorre com as cavernas. Por consequência do grande número de montanhas consideradas sagradas (em diversas crenças), algumas possuem cavernas que fazem parte de suas histórias e acabam, também, por dividir a sua sacralidade. Muitas, no entanto, são consideradas sagradas independentemente da outra. São consideradas, portanto, parte integrante das práticas religiosas de uma comunidade, valoradas como templos, igrejas, locais para meditação ou práticas ritualísticas.

Brito (2008, p.4) ainda afirma que, "mesmo um estudo pouco aprofundado das mensagens contidas no livro sagrado do cristianismo revela inúmeras menções a montes, montanhas e elevações: são citados o monte Carmelo, o monte Horeb, as montanhas de Efraim, o Tabor, o monte Moriá, entre outros".

Sobre as cavernas naturais ou artificiais citadas na Bíblia, o mesmo ocorre: as cavernas de Machpelah, Adullam e En-Gedi, entre outras, são retratadas no texto sagrado, surgindo também e, com freqüência, os termos: abismos, covas, fendas, grutas e cavernas. Uma pesquisa na Enciclopédia Arqueológica da Terra Santa (NEGEV; GIBSON, 2003), revela cerca de 100 itens relacionados ao termo caverna. Gibson (2008, p.110) lembra que "no primeiro livro de Samuel (14: 25-27) os Filhos de Israel 'chegam a um bosque e havia mel pelo chão', presumivelmente em fissuras e fendas nas rochas." (GIBSON, 2008, p.110).

No texto bíblico o subterrâneo apresenta-se como locais de moradia (Genesis 19:30, Números 24:21, Jeremias 49:16, Obadias 1:3), esconderijo (1 Samuel 13:6, 1 Samuel 14:11, 1 Samuel 22:1, 1 Samuel 23:29, 1 Samuel 24:3, 1 Reis 18:4, Hebreus 11:38), descanso (1 Samuel 24:3, 1 Reis 19:9), enterro (Genesis 23:19, Genesis 49:29-32, Genesis 50:13, João 11:38) ou como locais que não apresentam proteção contra os julgamentos divinos (Isaías 2:10, Isaías 2:19, Ezequiel 33: 27, Apocalipse 6:15). Abismos ou outras cavidades surgem também como prisões (Isaias 24: 18, Isaias 51:1, Zacarias 9:11). 
Covas abertas artificialmente também remetem-nos aos pequenos abismos espalhados pelas regiões cársticas, onde animais podem cair. Além disso, abismos eram considerados os portais da antiguidade greco-romana que ligavam esse mundo ao inferno, por exemplo. Certamente, o imaginário coletivo e a significação religiosa das cavernas variam de acordo com as religiões. Entretanto, traços comuns ou similares podem ser percebidos em diferentes culturas.

Mais recentemente, Mihevc (2001), Ferenc (2005) e Travassos (2009) identificam cavernas onde atrocidades foram cometidas durante e após a segunda Guerra Mundial . Utilizadas como locais para assassinatos em massa, muitos desses locais passam, hoje, por um processo de sacralização com a construção de memoriais ou cruzes próximas a esses espaços.

Para Kiernan (2003), o Cristianismo, professado por cerca de 33\% da população mundial, pode ser lembrado como a religião mais antropocêntrica já surgida, rejeitando o animismo e o panteísmo em detrimento de uma visão monoteísta. Mesmo assim, inúmeras cavernas ou feições cársticas são consideradas sagradas pelos Cristãos, como a Gruta de Massabielle (Gruta de Lourdes), onde uma garota católica (Bernadette Soubirous) afirmou ter presenciado dezoito aparições de Nossa Senhora em 1858, por exemplo. Ainda para o autor, no Islamismo (cerca de $22 \%$ da população mundial), a adoração de uma paisagem específica parece ser inaceitável, embora a Caverna de Hira (localizada no Monte Hira, próximo à Meca, Arábia Saudita) seja importante nesta crença, pois foi o local onde o Profeta Maomé teria recebido a revelação.

Nas tradições Hinduístas (15\% da população mundial), Budistas (6\% da população mundial) e crenças chinesas como o Taoísmo e o Confucionismo (4\%), as cavernas são locais importantíssimos. Comunidades indígenas ou nativas também identificam as cavernas como importantes locais em suas crenças (3\%). Para cerca de $14 \%$ dos indivíduos da população mundial, sem crença específica, mas não necessariamente completamente ateus, as cavernas não apresentam nenhum valor especifico (KIERNAN, 2003). 
Assim, percebemos que várias cavernas têm adquirido profunda significação espiritual em diversas partes do globo. Algumas carregam testemunhos físicos da adoção de sucessivas tradições enquanto, em poucos casos, outros espaços continuam sendo compartilhados por diferentes crenças.

No Brasil, de maioria católica $(73,6 \%$ da população total segundo o IBGE, 2000), existem cavernas-igreja que influenciam e, de certa forma, movimentam a economia local e o setor do turismo cultural e religioso.

Especialmente sobre as manifestações católicas, é possível identificar as cavernas como templos análogos às catacumbas utilizadas pelos cristãos perseguidos por Roma. Para o Instituto Salesiano São Callisto (2005), o decreto senatorial 35 declarava a religião cristã como "nova e estranha". Para Tácito, seria "perniciosa e detestável"; "malvada e desenfreada" por Plínio; "nova e maléfica" para Suetônio; "obscura e inimiga" da luz por Octavius de Minucio. Dessa forma, o catolicismo foi colocado como ilegal e perseguido por ser considerado o maior inimigo do poder de Roma, que se baseava na antiga religião nacional e no culto do imperador, instrumento e símbolo da força e unidade do Império.

Proibidos de exercer sua fé por um grande período de tempo, apenas puderam se libertar das "trevas" em 313, quando os imperadores Constantino e Licínio deram liberdade às práticas católicas, passando, a partir daí, a edificar igrejas na superfície. Talvez repouse nas catacumbas romanas a construção de altares ou mesmo de pequenas cavernas artificiais para proteção das imagens que antes não podiam ser cultuadas na superfície. Nesses locais, as criptas destinadas a personalidades mais importantes como papas e mártires apresentam, talvez, os primeiros registros da arte e arquitetura cristã.

Dessa forma, o espaço desprovido de valor passa a ser importante lugar de devoção para peregrinos que, atrelados à ideia de sacrifício pessoal, visitam tais sítios. Nas cavernas, uma variedade de objetos e formas são veneradas por sua beleza, supostos poderes milagrosos e associação a histórias locais. Acredita-se também que a água, que emana das rochas, permite a cura de uma vasta gama de doenças, atribuindo ainda mais um valor sagrado ao espaço. 
Assim, privilegiar os estudos humanistas-culturais do carste oferece possibilidades teórico-metodológicas indispensáveis à compreensão do fenômeno das romarias ou do turismo às cavernas-igreja. Não é possível, portanto, compreender os fenômenos apenas através do inventário, mapeamento ou simples descrição das formas físicas.

É importante ressaltar que muitas cavernas brasileiras ainda não são conhecidas em sua totalidade e outras permanecem inacessíveis à maioria das pessoas. Distantes dos centros urbanos, o cenário da escuridão propicia 0 surgimento e a permanência de mistérios que se recriam na tradição oral, enriquecendo as histórias locais.

Para os pesquisadores que trabalham com o meio ambiente e, principalmente, a gestão dos recursos naturais, é fácil perceber a dificuldade entre a gestão e o uso sustentável da natureza. Muitos afirmam que o setor do turismo está entre os maiores promotores da degradação. No entanto, acreditase que o turismo realizado de forma responsável pode atuar também na preservação ambiental.

Esse fenômeno complexo e multidisciplinar, por transitar pelas áreas da Geografia, Antropologia, Economia e da Sociologia, entre tantas outras disciplinas, merece atenção especial para ser percebido e realmente ser atuante como um verdadeiro agente de preservação e sustentabilidade.

Nesse contexto, as áreas cársticas surgem como geoecossistemas sensíveis e vulneráveis aos impactos da atividade turística. Ainda assim, não é aceitável acreditar que a simples proibição do seu uso para o turismo seja a única alternativa para sua conservação. Em alguns casos, atitudes drásticas e unilaterais podem impactar toda uma economia regional causando sérios impactos sociais.

Em relação ao uso cultural das áreas cársticas, o foco central deste trabalho é o estudo do seu uso cultural-religioso, expondo a urgente necessidade de mudança de postura em relação a essas manifestações culturais.

O turismo cultural ou as peregrinações a cavernas não são atividades novas. Pode-se afirmar que o turismo cultural no carste tenha começado na 
Idade Média, quando peregrinos buscavam conhecer cavernas sagradas e igrejas subterrâneas. Mesmo que existam pesquisadores contrários a essa idéia, Kranjc (1994) considera que, talvez, o turismo de peregrinações a uma caverna tenha começado com os três reis Magos ao visitar o recém nascido Jesus em uma gruta utilizada como estábulo, próxima a Belém.

Sendo assim, as cavernas e o carste constituem-se como importantes registros histórico-geográficos de regiões específicas. Muitas vezes apresentam traços comuns a várias culturas como será demonstrado ao longo do trabalho.

Em regiões que experienciaram guerras, $o$ carste $e$ as cavernas (especialmente os abismos) desempenharam um triste papel ao serem os locais onde pessoas foram assassinadas. Da mesma forma que surgiram na história como lugares associados ao mal, com o tempo passaram a ser sacralizados. Nestes locais onde o medo prevaleceu, foram e ainda são erigidos em suas proximidades, monumentos e oratórios em homenagem aos mortos. Esse fenômeno pode ser observado a medida em que as sociedades lutam por superar os traumas vivenciados por essas tragédias.

\section{PROCEDIMENTOS METODOLÓGICOS DA PESQUISA}

Como objetivo geral do trabalho, propõe-se a investigação do uso cultural do carste e das cavernas como base do Turismo Cultural. Através de levantamento bibliográfico, do estudo das áreas protegidas da UNESCO, da análise dos sítios visitados por Hayes (2005-2009), do estudo de quatro cavernas santuário específicas (duas no Brasil, em Minas Gerais) e duas na Eslovênia-Itália (Socerbska e Landarska) e da presença do autor em inúmeros sítios considerados sagrados, objetiva-se realizar um estudo que favoreça a divulgação do uso cultural do carste e das cavernas. Busca-se também, colaborar com as discussões sobre o uso religioso de cavernas e inserir a temática nos estudos de Geografia da Religião em particular, e da Geografia Cultural em geral. 
Sítios culturais e sagrados ocorrem em uma variedade de paisagens e, dessa forma, objetiva-se abrir um caminho em meio à Carstologia e à Espeleologia nacional, em um campo de pesquisas ainda muito pouco trabalhado sistematicamente no Brasil. Pretende-se contribuir para a união entre a preservação do patrimônio cultural do carste e a conservação do patrimônio geológico e espeleológico.

O trabalho fundamenta-se no aprofundamento teórico dos temas relacionados às paisagens cársticas e a relação com seu uso cultural e religioso, através de uma extensa revisão bibliográfica feita por Travassos (2010). Destaca-se a importância dos trabalhos de vários geógrafos importantes capazes de aliar os estudos físicos e humanos. São eles Humboldt, Malte-Brun, Reclus, Nicod e Gauchon. Outros naturalistas também foram citados por Travassos (2010) oferecendo maior peso à importância cultural do carste, mas por questões de espaço foram suprimidos to presente trabalho.

Devido à natureza dos trabalhos descritivos mencionados, optou-se por não separar cavernas artificiais de cavernas naturais. Sabe-se de suas diferenças, entretanto, uma separação destes dois tipos de cavidades não é possível por fragmentar excessivamente o texto.

A revisão bibliográfica se propôs a demonstrar e discutir a aplicabilidade de conceitos como topofilia, topofobia, sagrado e profano ao carste, relacionando-os a exemplos nacionais e internacionais. Essa etapa foi importante para a construção de um referencial teórico básico, essencial para o desenvolvimento da temática do trabalho.

Dada a natureza do objeto de estudo e os propósitos da investigação, optou-se por realizar uma pesquisa de caráter exploratório e descritivo, com algumas análises de cunho qualitativo e quantitativo, assim como proposto por metodologia da observação participante adaptada de Steil (1996; 2003), Evia Cervantes (2007) e Barbosa (2007; 2009).

Outra etapa foi realizada, entre os anos de 2006 e 2010, a fim de identificar o fenômeno do uso cultural e religioso do carste alternando a presença nos locais de culto em Antônio Pereira (Gruta da Lapa) e em Vazante 
(Lapa Velha), Minas Gerais e nas Grutas Sveta Jama (Caverna Santa) e Landarska Jama ou Sv. Ivan v Čele (Caverna de Landarska ou Gruta de São João na Rocha). Aqui, os dados históricos e geográficos teóricos foram confrontados com a percepção de campo do autor nestes e em outros sítios sagrados europeus que foram detalhados em Travassos (2010).

Essa abordagem metodológica levou em conta a observação participante dos peregrinos e dos turistas durante as festividades nas cavernas brasileiras e durante as visitas às cavernas europeias. Identificou-se, dessa forma, como se portam os indivíduos no espaço sagrado. Tais observações são complementadas por entrevistas informais semi-estruturadas com os participantes - tanto romeiros quanto turistas. Os diálogos cobriam as ideias básicas sobre a estória das aparições ou das lendas associadas, o conhecimento da gruta e outros relatos. Assim, as informações apresentadas fundamentaram-se na produção acadêmica sobre o assunto e nas informações orais coletadas durante os trabalhos de campo.

\section{VIAJANTES E GEÓGRAFOS CLÁSSICOS}

Acreditamos que dos estudos físicos da natureza, não é possível dissociar a figura de Alexander von Humboldt (1769-1859). Se pensarmos na Geografia, essa separação é ainda mais difícil. Turley (2001) afirma que muitos o consideram o fundador dessa Ciência, enquanto outros o chamam de o maior responsável pela ciência moderna como um todo. Kohlhepp (2006) também concorda que Humboldt contribuiu significativamente para o desenvolvimento e a consolidação da Geografia como ciência. Como geógrafo físico, iniciou os estudos climatológicos e fitogeográficos. Como geógrafo humano, engajou-se nos aspectos relevantes da geopolítica e da geografia humana dos estudos regionais. Como cartógrafo, representava a natureza muito didaticamente por meio de cartas e perfis belíssimos.

Para Amorim Filho (2008), Humboldt teve um papel importantíssimo junto aos pintores do "exuberante Novo Mundo" tropical. Tal afirmativa é comprovada por Diener (2007) que identifica, por exemplo, de que forma os 
trabalhos de Humboldt influenciaram o artista alemão Johan Moritz Rugendas (1802-1858). O naturalista Carl Friedrich Phillipp von Martius (1794-1868), também abordado no trabalho de Travassos (2010), assim como muitos de seu tempo foi influenciado por Humboldt. Henriques (2008, p.27) nos lembra esse fato quando afirma que, "como europeu, Martius certamente tinha grande curiosidade pela América, devido à leitura dos livros de Humboldt", frequentemente citado no diário de sua viagem pelo Brasil.

Mesmo com todos os trabalhos escritos sobre Humboldt e suas pesquisas, o que alguns ainda desconhecem, é sua importância para o estudo do carste e das cavernas. No Brasil, poucos ou nenhum trabalho foi feito no sentido de destacar como essas feições são mostradas em suas obras. Nas suas "Narrativas pessoais", "Nos Quadros da Natureza", no "Cosmos", no "Ensaio geognóstico sobre a sobreposição das rochas em ambos os hemisférios", no "Ensaio Político sobre o Reino da Nova Espanha" e na "A Ilha de Cuba", são descritas cavernas em maciços carbonáticos e graníticos, sumidouros, ressurgências e minerais diversos.

O uso do subterrâneo como moradia, abrigo, espaços para a prática de rituais funerários ou para adoração de deuses também são presentes em suas obras. Além de descrever os aspectos físicos da Caverna dos Guacharos, por exemplo, observou os ritos religiosos dos indígenas que estavam acostumados a celebrar cerimônias na entrada da caverna. Lá consultavam os espíritos poderosos que interviriam contra os espíritos malignos que habitavam a escuridão.

Os naturalistas Spix e Martius (1824) registram o carste apresentando indícios do uso religioso do subterrâneo, seja em cavernas naturais ou artificiais, tanto na Eslovênia quanto na Itália e África, antes de chegarem ao Brasil. No país, Spix e Martius (1824, p.277), viajam pelo interior da então colônia portuguesa passando também, por áreas cársticas. Na região do Quadrilátero Ferrífero, claramente mais interessados pelos metais preciosos e pelos processos de extração e beneficiamento, registram suas impressões sobre a Vila de Antônio Pereira e destacam a existência da Lapa de Antônio Pereira, desenvolvida nos dolomitos da Formação Gandarela: 
Em um aprazível vale, não muito distante da vila, um afloramento de calcário cinza claro se destaca na paisagem (...). É provavelmente calcário primitivo e (...) nele encontra-se uma caverna com estalactites, transformada na Capela de Nossa Senhora da Lapa (SPIX; MARTIUS, 1824, p.277).

\section{AS GEOGRAFIAS UNIVERSAIS DE CONRAD MALTE-BRUN ELISÉE RECLUS}

No escopo deste trabalho, a importância científica e cultural do carste continua sendo comprovada ao citar outros dois importantes geógrafos clássicos: Conrad Malte-Brun e Elisée Reclus. Para Amorim Filho (1988, p.18) as Geografias Universais, particularmente desses dois autores, foram escritas com o objetivo de "cobrir o conhecimento geográfico de toda a Terra, tendo como base divisões macro-regionais", desenvolvendo-se a partir da "escola geográfica" francesa.

A primeira das grandes obras de "inspiração enciclopédica do domínio da geografia européia foi a 'Geographie Universelle' de Conrad Malte-Brun, dinamarquês que foi obrigado a exilar-se na França em função de suas idéias, consideradas muito liberais para a época." (AMORIM FILHO, 1988, p.19). Tinha por objetivo propiciar uma renovação na geografia que 0 autor julgava ser de fundamental importância àquela época (AMORIM FILHO, 1988).

O carste e as cavernas são retratados sob a mesma ótica da integração dos estudos físicos e humanos. Inúmeras referências à geologia e ao tipo do calcário de várias regiões do mundo são feitas. Descrições de cavidades repletas de fósseis e concreções também são comuns nos 8 volumes existentes. Além disso, cavernas utilizadas como habitações e templos também são registradas. Muitos outros registros estritamente físicos sobre processos geomorfológicos e cavernas são encontrados na obra de Malte-Brun, entretanto, os esforços deste trabalho concetram-se mais em seu uso cultural e religioso pelo Homem.

Um breve exemplo que ilustra a afirmativa refere-se ao Monte Carmelo, em Israel e as catacumbas Capuchinhas de Palermo. Na obra Malte-Brun (1824, p.149) é informado sobre os supostos milagres de Elias e que, na 
região, "milhares de cristãos viviam em cavernas na rocha; a montanha era, então, coberta por capelas e jardins. Atualmente, nada pode ser visto a não ser as ruínas entre os carvalhos e oliveiras cujas cores verdejantes são interrompidas pelas rochas calcárias".

Em meados e fins do século $X I X$ ao século $X X$, surge, primeiramente, 0 nome de Elisée Reclus (1830-1905). Sobre Reclus, Amorim Filho (1988) afirma que o mais extenso dos trabalhos de Reclus e também o maior trabalho de geografia regional redigido por um homem só é a sua Nouvelle Géographie Universelle tornando-o famoso. "Mesmo que criticado por alguns geógrafos franceses como, às vezes, superficial em certos temas (bases geológicas da Geografia, por exemplo), o trabalho de Reclus só pode ser caracterizado como grandioso." (AMORIM FILHO, 1988, p.24). Em relação à temática deste trabalho, pode-se afirmar que em todos os 19 volumes desta Geografia Universal, há referências à temática das cavernas, dos sumidouros, das ressurgências e do uso do carste por diferentes culturas (TRAVASSOS, 2010).

Da mesma forma que os outros autores, os fenômenos cársticos que mais chamaram sua atenção foram as cavernas, dolinas, sumidouros e ressurgências. Frequentemente fez relação com as lendas associadas a esses locais.

Obviamente os volumes da Geografia Universal de Reclus não abordam completamente todas as províncias cársticas mundiais. Entretanto, muitos registros significativos são feitos e vêm comprovar a importância dos estudos da geografia histórica, humanística e física. Além disso, mostra a grande contribuição de um geógrafo francês do século XIX.

\section{A CONTRIBUIÇÃO MODERNA DE JEAN NICOD E CHRISTOPHE GAUCHON}

Também pertencentes à Escola Francesa, os nomes de Jean Nicod e de Christophe Gauchon devem ser lembrados ao se falar da importância cultural das cavernas. Muitas das cavernas hoje conhecidas apresentam indícios de usos sucessivos ou cumulativos ao longo da história, seja como fontes de água 
potável em locais assolados por secas sazonais ou com pouca disponibilidade de água superficial, seja como locais de proteção e uso religioso.

Nicod, Julian e Anthony (1996) ainda sugerem que a disponibilidade de água foi, entre outras coisas, responsável pelo desenvolvimento dos assentamentos humanos no carste. Os povos pré-Colombianos já utilizavam o carste e suas águas para sua sobrevivência. Os gregos foram os primeiros a canalizar a água das ressurgências de Siracusa, na Sicília. Já os romanos ficaram famosos pelas construções dos aquedutos que forneciam água abundante e fria para muitas de suas cidades. Durante a Idade Média, além do abastecimento, as águas cársticas eram utilizadas como fonte de energia motriz, assim como nos dias de hoje.

Ao relacionarem o uso das cavernas também como refúgios, Nicod, Julian e Anthony (1996) associam-nas também ao termo santuário contra os inimigos. Especialmente nos Bálcãs, existem inúmeros registros de cavernas que foram utilizadas por cristãos, klephts ${ }^{2}$ e hajdouks ${ }^{3}$ durante a dominação Turca. Na Europa ocidental, durante as Cruzadas, várias cavernas foram usadas e Day (2004) nos lembra que o carste Jamaicano foi um tradicional refúgio para os "Maroons", na resistência contra os ingleses de 1690-1796.

Já nó século XX, a utilização estratégica de cavernas europeias ocorreu na Grande Guerra e pelos Partisans da antiga lugoslávia e pela resistência francesa durante a Segunda Guerra Mundial. Nas guerras revolucionárias do Vietnã, Argélia, Líbano e Cuba, as cavernas também desempenharam um importante papel de proteção e refúgio (NICOD, JULIAN; ANTHONY, 1996).

Naturalmente, ao longo da história, tais cavernas-refúgio apresentaram fortificações em suas entradas. Na Eslovênia, os exemplos mais conhecidos são o Castelo de Predjama e a Caverna de Osp (Osapska Jama). Essa última ainda apresenta vestígios de um muro em sua entrada que tentava proteger os refugiados dos ataques dos turcos na região. Outra caverna, entre tantas na Eslovênia, também mostram os vestígios de um muro de proteção (a Šišca Jama).

\footnotetext{
${ }^{2}$ Comunidades gregas formadas após a conquista turca na Grécia.

3 Hajduks; Para Kranjc (2008), esses grupos formavam uma espécie de guerrilha contra a ocupação Turca nos Bálcãs. Podem ser considerados heróis por uns, ladrões por outros, dependendo do lado em que são percebidos.
} 
Sobre a Caverna Šišca, Malečkar (2005) lembra que há cerca de 400 anos atrás, após os Venezianos terem ateado fogo na região, somente metade da torre do castelo foi preservada e ainda pode ser vista hoje. Na parte posterior da torre, uma escarpa proporciona a visão geral do vale cego de Brezovica e cerca de 15 metros abaixo, é possível ver vestígios do muro de proteção da caverna. Para o autor a Caverna Šišca foi murada na segunda metade do século XIV, período em que os Turcos invadiram a região.

Pelas vantagens microclimáticas que proporcionam, muitas das cavernas naturais ou artificiais, foram e ainda são utilizadas como moradia temporária ou permanente. Em relação à função religiosa desses locais, muitas cavernas-igreja hoje existentes originaram-se também a partir de fortificações.

Essa função religiosa das cavernas é facilmente perceptível ao longo da história. Para Nicod, Julian e Anthony (1996) e Nicod (1998), podem ser basicamente divididas em três grande categorias de acordo com sua função: 1) mágico-religiosas; 2) sepulcros e 3 ) eremitérios cristãos e budistas. Acrescentaríamos à última categoria, eremitérios hinduístas. Na maioria dos casos, senão em todos, a água apresenta supostos poderes curativos e sagrados.

Cavernas também são apresentadas ao longo da história como santuários pagãos da Antigüidade, sobrevivendo ao tempo através das lendas. Essas, normalmente associando as cavernas com a moradia do mal e de outros seres. De acordo com Nicod, Julian e Anthony (1996), para sacralizar o profano, na entrada de muitas dessas cavernas foram construídas capelas geralmente dedicadas à São Miguel Arcanjo que supostamente bloquearia as entradas desses sítios amaldiçoados.

Já Gauchon (1997), na introdução de seu trabalho sobre as cavernas e os homens, cita Pierre Defontaines (1933) afirmando que a geografia humana encarrega-se especialmente de reunir as evidências da presença humana pelo Globo. Com base nessa afirmativa, Gauchon (1997) desenvolveu pesquisas demonstrando a importância cultural do carste francês. Identificou cavernas utilizadas como refúgios, santuários e diversos outros tipos de uso, como adegas e locais para fabricação de queijos. 
Ressalta-se que dos cinco capítulos da obra, 1 é dedicado ao uso das cavernas como santuários, tratando as cavernas como espaços santificados. 0 autor estabelece tipologias das "grutas-refúgio", a saber: 1) cavernas fortaleza reais, 2) refúgios stricto sensu e 3) postos de vigília. Em relação aos usos diversificados, o autor menciona a existência das seguintes categorias: 1) abrigos subterrâneos (pequenos e grandes), 2) locais para exploração de recursos renováveis e não-renováveis do endocarste (água potável e uso de espeleotemas, por exemplo), 3) queijarias tradicionais e 4) turismo espeleológico ou espeleoturismo.

Especialmente para os geógrafos, tais tipos de uso dos espaços subterrâneos remetem ao significado dos conceitos do espaço e do lugar, frequentemente associados às paisagens naturais e, em especial, às cavernas.

\section{OS CONCEITOS DE ESPAÇO, LUGAR, IMAGINÁRIO, TOPOFILIA, TOPOFOBIA E A RELAÇÃO HUMANA COM AS CAVERNAS}

Assim como os trabalhos de Humboldt, é igualmente impossível esquecer os trabalhos de Yi-Fu Tuan relacionados com a percepção humana do ambiente. Dessa forma, relacionar os conceitos de espaço e lugar ao carste é tarefa de extrema importância para o desenvolvimento do trabalho.

Rodaway (2007) nos lembra que, embora os primeiros trabalhos de YiFu Tuan tenham sido realizados na área da geomorfologia (estudando pedimentos no sudoeste do Arizona), sua reputação foi estabelecida como um geógrafo cultural, sendo responsável pela redefinição da Geografia Humana como o estudo das relações entre o ser humano e o ambiente.

É preciso lembrar, portanto, dos conceitos de espaço, lugar, topofilia e topofobia. Como definido por Yi-Fu Tuan, topofilia é a relação ou conexão afetiva entre as pessoas e o lugar. Essa relação é influenciada por diversos fatores, entre eles, o background cultural e as circunstâncias históricas nas quais vive uma sociedade. Hoelscher (2006) afirma que Tuan considera que os componentes biológicos e sensoriais também devem ser levados em conta. Sendo assim, afirma que a topofilia talvez não seja a mais forte das emoções humanas (devido à variedade de respostas a determinado ambiente), 
entretanto, quando "ativada" possui o poder de elevar o espaço à categoria de lugar. Tal sentimento geralmente possui uma conotação de relação positiva, podendo, dependendo do indivíduo, ser trocado por um sentimento de "topofobia". Ao estudarmos a relação humana com as cavernas, tais sentimentos são mais facilmente percebidos.

Para Tuan (1980; 1983), o lugar é uma unidade de espaço organizada mentalmente e materialmente para satisfazer as necessidades bio-sociais básicas reais ou percebidas, de um povo. Além disso, suas aspirações estético-políticas superiores também podem ser expressas pela "transformação" de um espaço em lugar. Dessa forma, um espaço desprovido de valor transforma-se em lugar para um indivíduo ou grupo social, quando esses passam a possuir um sentimento de pertencimento.

O lugar refere-se, mais tipicamente, a um segmento particular da superfíce terrestre, caracterizado por esse sentimento de pertencimento que 0 faz ser diferente dos demais. Assim, podemos considerar o lugar como a porção mais significativa do espaço (CRESSWELL, 2006). As cavernas consideradas sagradas em diversas culturas comprovam tais afirmações.

Ainda sobre o lugar, Tuan (1980; 1983) e Rosendahl (2007) afirmam que sua concepção é um ato social, diferindo-se entre si, pois as pessoas os fizeram assim. Não são simplesmente o resultado não intencional de processos econômicos, sociais e políticos; são, também, sítios potenciais de fontes de conflito.

No caso de cavernas-santuário ou cavernas-igreja, essa última característica de ser fonte de possíveis conflitos pode ser sentida seja entre os órgãos ambientais, os ambientalistas e os fiéis ou entre fiéis de diferentes tradições como ocorre no Oriente Médio ou na Índia, por exemplo.

A imagem das cavernas no imaginário popular ou mesmo na mitologia é, geralmente, relacionada a locais de escuridão e abandono. A partir dessa percepção, as cavernas são vistas preconceituosamente como locais onde o medo domina. Em outros casos, são percebidas como o lugar de morada de deuses e deusas. Outras representações relacionam esse ambiente à ressurreição ou ao local onde figuras religiosas ou sagradas estiveram. Essa 
clara oposição entre os sentimentos topofóbicos e topofílicos, respectivamente, é motivo de reflexão por parte de filósofos e religiosos ao longo da história.

É, portanto, a partir da relação de conflito existente entre o Homem e o espaço onde a luz, a sombra e a escuridão se combinam harmoniosamente, que brotam os sinais "que tentam explicar o que é lógico, real ou imaterial" (BARBOSA, 2007). Nesse contexto, faz-se necessária a compreensão dos conceitos da tradição oral, dos mitos e dos símbolos. Os trabalhos de Cervantes (2006; 2007) e de Eliade (1991; 1994) proporcionam a base necessária para a compreensão do imaginário coletivo em relação a mitos. No Brasil, especialmente na comunidade espeleológica, o estudo do imaginário das cavernas é ainda relativamente novo.

Recebeu importantes e significativas contribuições iniciais de Figueiredo (1999; 2001), Gomes (2003), Mendes (2003), Silva (2003), Teixeira (2003) e Figueiredo, Travassos e Silva (2009), sendo continuado sob a ótica da percepção ambiental e do uso religioso das cavernas por Travassos et al. (2006), Kranjc e Travassos (2007), Guimarães, Travassos e Varella (2007; 2009), Travassos et al. (2007), Travassos (2007d), Travassos e Varela (2008) e Travassos et al. (2008). Importantes contribuições são também feitas por Barbosa, Nogueira e Neves (1999), Barbosa (2007), Barbosa e Travassos (2008), também sob a ótica do uso religioso das cavernas.

A beleza da paisagem cárstica e das cavernas constitui-se, segundo Teixeira (2003, p.11), no "fator de referência para o desenvolvimento do universo imaginário (...), elemento propulsor do nascimento de lendas e 'causos' associados a mitos mais gerais”. Esse imaginário em relação às cavernas é expresso na tradição oral das comunidades tradicionais e serve para auxiliar os pesquisadores no entendimento dos comportamentos ambientalmente corretos ou não de cada grupo social. Esse imaginário pode estar relacionado aos sentimentos de medo (topofobia) ou afinidade (topofilia), ambos comuns aos visitantes das cavernas, sejam elas cavernas-igreja ou cavernas-santuário.

Para Cervantes (2006; 2007), a tradição oral apresenta-se como o conjunto de testemunhos "impressos" na memória coletiva de um grupo. 
Manifesta-se na comunicação entre os integrantes de uma sociedade ou uma comunidade específica. Seus conteúdos são elaborados, reelaborados e transmitidos oralmente pelos integrantes das gerações anteriores aos membros da sociedade atual. Para o autor seu estudo é tarefa difícil, porém, gratificante. Trata-se, principalmente, de ouvir as pessoas, como dizem, quando dizem e porque dizem. As lendas ou estórias fabulosas de milagres e aparições criam um ambiente enigmático; a atmosfera da narrativa torna-se misteriosa e, muitas vezes, o sentimento de respeito é experimentado na voz do narrador.

Por isso, especialmente no tocante à relação humana com as cavernas, observa-se que seu estudo formal ainda é escasso e praticamente desconhecido nos meios urbanos. Isso é facilmente percebido nas entrevistas com os moradores ou com os romeiros nas cavernas-igreja. Muitas vezes o simples turista não tem acesso a essas narrativas.

Assim como apontado por Cervantes (2007) em seus estudos no México, é possível afirmar que o Brasil também possui uma tradição oral muito rica. Essa tradição propicia o surgimento de mitos e símbolos que atravessam os séculos. Na América do Sul, Cervantes (2006) afirma que "sua mitologia de hoje" é composta por testemunhos originários tanto de épocas pré-hispânicas quanto de relatos mais atuais. Essas fontes públicas e anônimas abordam assuntos importantes e sérios relacionados à existência e à sobrevivência da comunidade.

Para Limón (1990) citado por Cervantes (2007), os mitos proporcionam as respostas satisfatórias às preocupações profundas do ser humano. Eliade (1992, p.50) afirma também que é um "modelo exemplar", que conta uma história sagrada ou um acontecimento primordial, que teve lugar no começo do tempo e, uma vez dito ou revelado, torna-se verdade. Assim, fixa os modelos dos ritos e das atividades humanas.

São, portanto, fenômenos complexos que dificilmente podem ser explicados por uma única teoria. As cavernas e o carste são justamente o cenário para o surgimento de inúmeros mitos e o desenvolvimento do imaginário coletivo das cavernas. Uma vez que se atribui a uma caverna a 
aparição de um santo(a) ou o refúgio de um beato(a), por exemplo, dificilmente esse lugar deixa de ser venerado em favor de outro.

Dessa forma, as cavernas surgem no contexto apresentando pinturas rupestres e dando suporte à construção de templos, esculturas, rituais, etc. Com os relatos dos naturalistas e geógrafos citados anteriormente, percebe-se que alguns símbolos dominantes chegam a se estender por extensas áreas geográficas, expressando-se em múltiplos contextos e até continentes. $\mathrm{O}$ mais notável é a relação das cavernas com as serpentes que apresenta-se similar em várias culturas.

Cervantes (2006) destaca que região de Yucatan, América Central, é rica em elementos do imaginário. Na região, a serpente Tsukán vive, cuida ou é dona de uma caverna ou cenote. Os relatos afirmam que é tão grande que sua cabeça é como a de um cavalo; quem a encontra menciona o brilho de seus olhos na obscuridade da noite ou da caverna. O encontro com o ser é temido pelos moradores rurais, pois caso a matem, uma desgraça certamente ocorrerá na família. Esta pode ir desde paralisia temporal, febres, enfermidades, lesões permanentes ou até a morte. Relatos ainda dão conta de que, devido a seus poderes extraordinários, a Tsukán se alimenta apenas abrindo a boca quando, então, suas presas entram para ser devoradas (CERVANTES, 2007).

No Brasil, uma entidade similar à mexicana foi descrita por Segura (1937), sendo reproduzida por Steil (1996), como demonstrado anteriormente. De maneira geral, Cascudo (2001) afirma que, segundo a tradição portuguesa, existe no interior do país uma serpente que procura as mães que amamentam os filhos, surpreendendo-as durante o sono para sugar-lhes o seio. O autor lembra que tal narrativa é parecida com a lenda das mouras encantadas de Portugal.

"Para o povo, elas [as serpentes] apresentam poder misterioso de vitalidade e de força; símbolo do mal e da sabedoria; símbolo diabólico e da tentação do mal, resistindo nas fórmulas exorcistas católicas" (CASCUDO, 2001, p.632), "onde, em algumas regiões, monstros arrastam o imenso corpo pelas montanhas" (CASCUDO, 2002, p.14). 
De acordo com Ronecker (1997) a serpente é, sem dúvida, o animal que provocou mais interpretações míticas e simbólicas. Possui valores simbólicos variados e contraditórios. Benéficas para uns, maléficas para outros. É a prima mítica do dragão.

Um exemplo dessa relação pode ser observada mesmo no "Velho Mundo", na Europa Medieval, quando Čuk (2008) registra uma lenda associada à Caverna de Postojna: conta a lenda que, há muitos anos atrás, um terrível dragão teria vivido nessa caverna aterrorizando os moradores da vila até que foi bravamente derrotado por um pastor da região.

Essa passagem nos mostra, talvez, o papel desempenhado pelas "trevas" da caverna ao povo daquela pequena cidade europeia, como forma de abrandar o temor da população em relação à escuridão incompreendida. Para Tuan (1979/2006), os medos são experimentados particularmente por cada indivíduo, sendo por isso, subjetivos; alguns, entretanto, são produzido por um meio ambiente ameaçador. Para o autor, o próprio conceito de paisagem, como o termo tem sido utilizado desde o século XVIII, é uma construção da mente, assim como uma entidade física mensurável. A "paisagem do medo" (TUAN, 1979/2006, p.12) diz respeito tanto aos estados psicológicos, como ao ambiente real.

Os dragões do imaginário europeu continuam relacionados às cavernas ou ao carste: Na obra "Mundus Subterraneus" de Kircher (1678), são ilustrados pelo menos 5 tipos de dragões e a clássica luta entre o homem e esse ser. No século XVII, um famoso explorador alpino chamado Johann Jacob Scheuchzer, dedicou-se ao estudo das plantas, minerais e movimentos do gelo dos Alpes europeus de 1702 a 1711. À época teria sido responsável, inclusive, pela catalogação dos dragões suíços. Segundo Scheuchzer, "os melhores dragões viviam em Grisons, o maior e mais escassamente povoado dos cantões suíços. A região é tão montanhosa e com tantas cavernas, que seria estranho não encontrar aí, dragões." (BERR apud TUAN, 2006, p.129).

Cervantes (2006) destaca que os temores dos habitantes de áreas rurais em relação às grutas vão desde de se perderem nos labirintos até caírem em algum abismo interior. Além disso, apresentam-se como sítios especiais 
dotados de valor sobrenatural, como a Gruta Xpukil, no povoado de Calcehtok e o cenote K'oop. De acordo com as comunidades, as grutas podem se fechar se desrespeitadas (lenda similar a gruta do Lapão Velho, na Bahia) e para que nada ocorra ao entrar no cenote, é necessário levar oferendas (cigarros, água e comida).

Nas Ilhas Fiji, Eliade (2002) registra a suposta existência de uma divindade celeste chamada Ndengei. Representada na forma de uma serpente, vive em uma caverna. Quando incomodada ou quando se agita, a terra estremece. "Embora seja também criadora do mundo, é onisciente e punidora do mal." (ELIADE, 2002, p.50).

Kejonen (1997) destaca que, das 750 cavernas conhecidas na Finlândia, cerca de 473 estão ligadas a algum tipo de tradição popular ou narrativa oral. Nestes registros, cavernas foram utilizadas por xamãs, eremitas, ladrões, assassinos, refugiados de guerras, trabalhadores e caçadores. Para esses últimos, muitas cavernas ainda servem como locais de abrigo, apresentando modificações antrópicas. Em relação ao imaginário, as cavernas como morada de seres sobrenaturais também são identificadas.

Sobre a relação entre a presença de criminosos em cavernas, Cardoso (2006) destaca a lenda relacionada à Gruta da Moeda, em Fátima, Portugal. Segundo a estória, um homem rico da região, a passar por um matagal, foi atacado e saqueado por um bando de criminosos. Após matá-lo, teriam jogado seu corpo em um abismo. No momento em que atiravam seu corpo às profundezas, deixaram cair o saco de moedas na caverna, perdendo-as para sempre.

$\mathrm{Na}$ Austrália, Hamilton-Smith (1987) afirma que qualquer espaço "selvagem" favorece a criação de mitos e lendas e as cavernas australianas também estão incluídas nesse cenário. Assim, identifica exemplos de mitos sobre abismos sem fundo, conflitos entre aborígenes e colonizadores, bem como a existências de heróis populares que utilizaram-se de tais espaços.

Clark (2007) apresenta um artigo sobre o imaginário dos aborígenes australianos afirmando que o estudo das associações feitas pelos aborígenes e as cavernas devem ser vistos como um rica fonte de informações culturais. 
Assim como em outras culturas, as cavernas, dolinas e sumidouros desempenharam e ainda desempenham um papel importante na vida dessas comunidades tradicionais. Frequentemente são retratadas como a morada de heróis ancestrais, espíritos e criaturas maléficas e até mesmo o local de descanso após a morte.

Muitos relatos compilados por Cervantes (2006) mostram que é comum a percepção de que as grutas e deidades associadas ao subterrâneo possam castigar ou proteger. Os maus comportamentos seriam punidos por uma deidade, seja Deus ou Satanás. Em algumas regiões de Yucatan, não se pode entrar nas cavernas durante a Semana Santa. Em 1995, a desobediência desta regra causou a morte de pessoas que não respeitaram a tradição. $\mathrm{O}$ autor ainda lembra que, caso uma gruta seja profanada, uma força sobrenatural pode infligir castigos severos.

Dessa forma, "é necessário abordar as paisagens do medo tanto da perspectiva do indivíduo quanto do grupo social e colocá-las ainda que sob a forma de tentativa, em um marco histórico" (TUAN, 1979/2006, p.15) pois, "à medida que o homem aumenta o seu poder sobre a natureza, diminui o medo que se sente dela."(TUAN, 1979/2006, p.16). Por essa razão, acredita-se na utilização da Educação Ambiental direcionada a áreas cársticas e cavernas.

No norte da Irlanda, Steward (2005) lembra da existência de um centro de peregrinação medieval, o Purgatório de São Patrick. Tal caverna era considerada nas lendas regionais como a entrada para o inferno. Localizada em Donegal, acredita-se que São Patrick teria morado na cavidade onde teria vencido inúmeras tentações e recebido, inclusive, uma visão do que seria o inferno. St. John D. Seymour (1918) registrou que na gruta, St. Patrick teria iniciado o processo de conversão dos Irlandeses ao cristianismo. Até hoje o local recebe uma peregrinação anual de centenas de milhares de pessoas.

Ainda sobre a relação do subterrâneo com a crença da existência do inferno, Steward (2005) afirma que o deus Chinês da misericórdia, Ti-Tsang Wang, andaria por cavernas infernais em busca de almas para serem salvas do submundo. 


\section{A GEOGRAFIA DA RELIGIÃO E OS CONCEITOS DE SAGRADO X PROFANO RELACIONADOS AO CARSTE E AS CAVERNAS}

Com o que foi exposto até 0 momento percebe-se o porquê das cavernas e abrigos sob rocha terem sido sacralizados ao longo da história das sociedades. O uso ritual de tais espaços foi, com o tempo, imprimindo uma marca característica na paisagem por meio da cultura. Acredita-se que as cavernas, sejam elas em carbonatos ou em rochas siliciclásticas, naturais ou artificiais, são os exemplos mais notáveis desse tipo de interação entre o Homem, a paisagem e a cultura.

Gil Filho (2007a) afirma que a religião é parte indissociável da experiência humana e, por esse motivo, o homem não fica passivo diante da realidade imediata e tenta buscar os significados da existência através da prática simbólica.

Um exemplo que ilustra essa busca de significados ou a impressão cultural nas cavernas é demonstrado por Shaw (2006). O autor afirma que vários nomes de salões e espeleotemas de cavernas do mundo inteiro derivam de formas arquitetônicas e outros objetos como animais, aves, plantas, partes de igrejas e até mesmo da própria anatomia humana. Nomes também são dados para evocar cidades ou monumentos que as fazem notáveis, além de serem comuns nomes sagrados ou de heróis nacionais e exploradores.

Alguns exemplos pertinentes a esse trabalho são a Caverna de Madalena (Črna Jama), nome dado por sua proximidade à Igreja de Santa Maria Madalena, por exemplo. Na Caverna de Postojna, ao longo da história, espeleotemas e salões receberam os nomes de Altar, Altar-mor, Santa Madalena, Santo Antônio de Pádua (Sv. Anton Padovano), Fonte batismal, Papa, Calvário, Capela, Grande Monte Calvário, Grande Catedral, Caverna de Santa Catarina, Cadeira de São Pedro, Monte Calvário, São Estevão e, também, Inferno. Tal fato também é notado por Cardoso (2006, p. 103) que destaca alguns dos nomes dados aos espeleotemas da Gruta da Moeda, em Fátima, Portugal. Os espeleotemas são nomeados de presépio, pastor, Virgem, capela imperfeita e fonte das lágrimas, por exemplo. 
Assim, LeBon (2002) afirma que o meio social exerce uma ação significativa sobre as opiniões humanas. A despeito da vontade, o meio social determina interferências inconscientes que dominam o grupo social. Isso é o que geralmente ocorre com a concepção das pessoas em relação às cavernas: "Em matéria de opiniões e de crenças individuais, deduzidas das nossas próprias observações e dos nossos raciocínios, temos geralmente muito pouco." (LeBON, 2002, p.198). Para o autor, "os homens, na sua maioria, somente possuem opiniões coletivas." (LeBON, 2002, p.195). Para Rosendahl (2007), a prática religiosa que se traduz na ida ao santuário, por exemplo, representa uma das várias formas pelas quais a religião age sobre pessoas e lugares.

Nas cavernas sagradas, esses lugares simbólicos são praticamente criados pela ocupação humana dos espaços e pelo uso de símbolos transformadores do espaço em lugar. A "força propulsora" desses lugares é a variação espaço-temporal do fluxo de peregrinos e a maior ou menor intensidade dos fluxos. Essa intensidade de fluxos aos lugares sagrados produzem as escalas de peregrinação como locais, regionais e internacionais. Inúmeras cavernas encaixam-se em nas três escalas.

Mas o que seria o sagrado ou o chamado lugar sagrado? Para Caillois (1988, p.15) "sobre o sagrado em geral, a única coisa que se pode afirmar com validade está contida na própria definição do termo: é que ele se opõe ao profano." Se opõe ao profano ainda que não sofra modificação física aparente. Depois de sacralizado, o espaço não mais pode ser utilizado livremente. Eliade (2002, p.372) também afirma que "a maneira mais simples de definir o sagrado é opô-lo ao profano."

Eliade (1992, p.13) ainda afirma que "o homem toma conhecimento do sagrado porque este se manifesta, se mostra como qualquer coisa de absolutamente diferente do profano." Entretanto, Galimberti (2003, p.11) explica melhor o conceito exposto ao registrar que

sagrado é uma palavra indo-europeia que significa "separado". A sacralidade, portanto, não é uma condição espiritual ou moral, mas uma qualidade inerente ao que tem relação e contato com potências que o homem, não podendo dominar, percebe como superiores a si 
mesmo, e como tais atribuíveis a uma dimensão, em sua vida denominada "divina", "separada" e "outra" com relação ao mundo humano (GALIMBERTI, 2003, p.11).

Em relação às cavernas, vemos uma tendência de sacralização, com maior ou menor intensidade, em diversos sistemas de crença religiosa. Para Perera (1988), as cavernas começaram a ser convertidas em sepulturas naturais (e talvez possamos dizer que em lugares sagrados) já a partir do neolítico. Na mitologia grega, à heróis lendários é outorgada a imortalidade em grutas e abismos profundos, reservando a estes, certa sacralidade. Caillois (1988, p.19-23) afirma que em qualquer concepção religiosa do mundo ocorre "a distinção do sagrado e do profano, onde o último é constantemente impelido a apoderar-se do sagrado." Talvez por isso, suas relações mútuas são regulamentadas através dos ritos.

Como proposto no início do presente trabalho, não é a intenção do autor do presente artigo o aprofundamento da compreensão do fenômeno religioso e, sim, aplicar os conceitos a esse tipo particular de uso das cavernas. Por essa razão, lembramos Eliade (2002, p.07) ao afirmar que "todas as definições do fenômeno religioso apresentadas até hoje mostram uma característica comum: à sua maneira, cada uma delas opõe o sagrado ao profano (...)." Assim, "delimitar o sagrado é tarefa difícil." (ELIADE, 2002, p.07). Devido à grande heterogeneidade dos documentos religiosos, Eliade (2002) ainda afirma que é difícil estudar tais fenômenos. Cada um constitui uma manifestação do sagrado no universo mental daqueles que o perceberam (ELIADE, 2002). Ainda assim, percebe-se que os espaços subterrâneos considerados sagrados possuem semelhanças entre si.

Para Eliade (1956) citado por Hassner (2002), os espaços sagrados são centros religiosos onde o céu e a terra se encontram tornando o meio de acesso do Homem ao Divino. Sendo assim, destaca-se que um lugar sagrado possui pelo menos três características: 1) são locais de comunicação com o divino através da oração, movimentação ou contato visual com a imagem do divino; 2) são locais da presença divina que promete cura, sucesso ou salvação e; 3) locais que dão significado à fé através da reflexão metafórica. Estas três características combinadas transformam o espaço sagrado em um centro 
religioso: para o crente, o lugar sagrado torna-se o centro do mundo espiritual ou geográfico.

As cavernas-santuário, muitas delas localizadas em imponentes afloramentos ou em posições elevadas no terreno, lembram o conceito de "alto", consolidado por Eliade (2002, p.40):

\footnotetext{
O "alto" é uma dimensão inacessível ao homem como tal; pertence por direito às forças e aos seres sobrehumanos; o que se eleva, subindo cerimoniosamente os degraus de um santuário ou a escada ritual que conduz ao céu, deixa então de ser um homem; as almas dos defuntos privilegiados.
}

As cavernas consideradas sagradas são, geralmente, espaços impregnados de formas e objetos que comunicam significados religiosos ao longo do tempo. "No interior do recinto sagrado" (ELIADE, 1992, p.19) o profano é sacralizado, favorecendo uma abertura para o alto que assegure a comunicação com o mundo dos deuses (ELIADE, 1992).

Para Gibson (2008), no geral, os espaços sagrados são percebidos como sendo abrigados dentro de um templo ou santuário. Entretanto, no passado, os lugares de adoração aos deuses, espíritos e seres cultuados podiam estar em qualquer lugar da paisagem. Podiam estar em uma árvore, gruta, em uma montanha ou até mesmo, em uma pilha de pedras. Assim, os "santuários são lugares de passagem entre o céu e a terra" (ELIADE, 1996, p.41).

O cientista ou aqueles que não fazem parte de determinado grupo social, segundo Eliade (1996, p.26), experimentam certo mal-estar diante das formas de manifestação do sagrado pois; "para muitos é difícil aceitar que, para certos seres humanos, o sagrado possa manifestar-se em pedras ou em árvores (...); não se trata de venerar a pedra como pedra e, sim, como uma hierofania"; ou seja, uma manifestação do sagrado. Da mesma forma, acreditamos que não se trata de venerar a caverna como caverna e sim como lugar onde supostamente se manifestou ou se manifesta o sagrado. Eliade (1992, 1996) afirma que os lugares sagrados guardam uma qualidade excepcional única que é a de ser o lugar sagrado do universo privado. É a escala, portanto, que cria o fenômeno. 
Berger (1994) lembra uma caverna sagrada ao leste do Nepal. Lugar de peregrinações Budistas e Hinduístas, a caverna é visitada por Sherpas Budistas (Grupo etnicamente Tibetano oriundo do nordeste do Nepal). Para este grupo, a visita à Caverna de Maratika é feita para "ganhar" ou "acumular mérito", prática comum aos devotos do Budismo. O sítio sagrado se localiza no Distrito de Khotang, $185 \mathrm{~km}$ ao sudoeste do Monte Evereste. Assim como em muitas outras cavernas do tipo, em Maratika tanto Budistas quanto Hinduístas atribuem a sacralidade da caverna à uma manifestação do divino.

Para os Hinduístas, a caverna é o lugar de adoração de Mahadev (um dos muitos nomes de Lord Shiva) que se manifesta em uma estalagmite na forma de linga (ou falo) localizada no fundo da caverna. Os Budistas, por sua vez, consideram a caverna como sendo sagrada pelo fato de ter sido utilizada pelo Guru Padmasambhava em seu caminho até o Tibete para introduzir o Budismo na região (BERGER, 1994).

Mais uma vez, a tradição escrita e oral legitima e permite a prática sóciocultural da peregrinação em função de uma feição endocárstica. Ao realizarem uma jornada ao poderoso lugar sagrado, deixando oferendas e participando dos rituais, os peregrinos esperam obter todos os seus objetivos individuais.

Para Perera (1988), a espeleologia histórica e a antropologia dividem alguns aspectos teórico-metodológicos que se centram na percepção e utilização cultural das cavernas, tanto para a sobrevivência quanto para o uso sagrado. Essa utilização sagrada das cavernas ocorre em um dado momento histórico onde o sagrado se manifesta. Em outros casos, Eliade (2002, p.355) lembra que, em algumas culturas, "certas pedras se tornam sagradas porque as almas dos mortos - dos antepassados - se encarnam nelas ou então porque manifestam ou representam uma força sagrada, uma divindade ou ainda porque um pacto solene ou um acontecimento religioso tiveram lugar na sua vizinhança."

Em muitas histórias da mitologia, a montanha sagrada apresenta-se como uma "variante mais ou menos ilustre do Olimpo Grego. Todos os deuses possuem lugares reservados ao seu culto nos pontos altos" (ELIADE, 2002, p.91), a fim de que a condição humana fosse transcendida "pelo fato de 
penetrar numa zona sagrada (templo, altar), pela consagração do rito, pela morte, exprime-se constantemente por uma 'passagem', uma 'subida', uma ‘ascensão'. (ELIADE, 2002, p.92).

A capela de S. Michele dei Pagani (São Miguel dos Pagãos) em Braulins, municipalidade de Trasaghis, Itália, ilustra essa afirmativa. Para chegar à capela, é necessária uma subida da base do afloramento até o abrigo sob rocha, onde foi erigido o sítio sagrado.

Mylroie et al. (2006) afirma que o Monte Alvernia, na llha Cat (Bahamas) possui as 14 estações do calvário, que levam o turista ou fiel até uma Igreja no alto da colina. Anson (1957), Evans (1984) e Taylor (2000), citados por Mylroie (2006), afirmam que o padre anglicano John Hawes, convertido ao catolicismo, habitou uma caverna nessa montanha durante a construção da Igreja. Nomeou-a Gruta de São Francisco de Assis e erigiu um altar para celebração de missas regulares para a população local. Uma pequena caverna, próxima ao topo do caminho onde se encontra a Igreja, foi escolhida como sua catacumba.

Ainda sobre santuários em abrigos sob rocha ou em cavernas, Stoev e Stoychev (1992) comparam dois existentes na Bulgária, onde ocorreriam rituais primitivos. A medida do tempo por sociedades primitivas servia não somente para atividades práticas do dia-a-dia mas, também, para a realização de cultos e rituais lunares.

Antonov (1977) destaca cavernas sagradas nas montanhas Strandža, no sudeste da Bulgária. O "Clube de Expedições Científicas" do país organizou uma expedição para um estudo detalhado das cavernas da região entre 1975 e 1976. Mais de 60 cavernas e abismos foram encontrados e estudados, muitos contendo interessantes achados arqueológicos. Além daquelas de Strandža, mais de 20 cavernas são conhecidas na Bulgária com evidências suficientes para serem consideradas sagradas pela população local. Em todas elas havia uma fonte, um pequeno lago, água gotejando do teto ou minando pelas paredes, todas com supostas propriedades curativas.

De acordo com Stamenova e Zhalov (2008) as terras Búlgaras podem ser consideradas uma região de contato e interação cultural por mais de 1.000 
anos. Por esse motivo, apresenta inúmeros e importantes sítios arqueológicos e as cavernas não são uma exceção a esta regra. Tais sítios apresentam uma enorme quantidade de registros culturais passados e, ironicamente, são justamente os lugares mais agredidos pelas atividades antrópicas.

Em Gibraltar, Gutiérrez López et al. (2001) afirmam que, quando os ribeirinhos se aventuraram pelo Mediterrâneo e a comunicação entre os extremos do Mare Nostrum se fizeram constantes, os navegantes deram início a um processo de sacralização das ilhas, cabos e promontórios costeiros. A existência de tais lugares sagrados foi transmitida pelos autores gregos e romanos da antiguidade clássica e, por isso, no entorno de Gibraltar são conhecidos templos e altares dedicados à Hércules, filho de Zeus. Com seus estudos na Caverna de Gorham, os autores afirmam que o sítio era o local de culto de uma ou mais divindades, sendo um santuário aberto de caráter "internacional" devido à presença de diversos artefatos encontrados durante as escavações.

Na Peştera Rece (ou Cold Cave), nas montanhas Bihor, na Romênia, Lascu et al. (1994) acreditam que a caverna tenha sido utilizada para uma espécie de culto primitivo ao urso. Embora possa haver críticas em relação à teoria da prática de um antigo ritual de adoração, os autores indicam outros trabalhos que datam de 1917 a 1977 onde foram registrados indícios similares de arranjo de ossos de ursos dentro de outras cavernas como alguma forma de oferenda para caça. Tal organização foi observada em diversas cavernas romenas desde 1672.

Além das posições de destaque no terreno, os locais sagrados no carste e nas cavernas manifestam-se também por causa dos supostos poderes de suas águas. Eliade (2002, p.155) afirma que "o mito mais importante das llhas de Trobriand [Ilhas ao longo da costa oriental da Nova Guiné] revela que Bolutukwa, a mãe do herói Tudava perdeu a virgindade em consequência de algumas gotas de água caídas de uma estalactite." As Ninfas, comuns na literatura Helenística, são as "divindades que residem também nas cavernas em que há umidade" (ELIADE, 2002, p.166), sendo comum a descrição da existência de diversas "Grutas das Ninfas". 
Håland (2009) identifica rituais sagrados pré-Cristãos e Cristãos relacionados com a água subterrânea na Grécia. Se antes as fontes de água representavam as Ninfas, hoje, tais lugares são dedicados à Nossa Senhora (Panagia) e possuem supostos poderes curativos. A autora ainda lembra que os moradores de Atenas e do entorno vão à Gruta de Nossa Senhora da Lapa na primeira sexta-feira após o domingo de Páscoa para ter contato com 0 sagrado.

A caverna se localiza na vertente sul da Acrópolis e a fonte se localiza no interior de uma caverna na qual foi construída uma igreja. A autora baseouse em trabalhos de campo durante os rituais religiosos contemporâneos para compará-los com os registros da Antiguidade, realizando uma interessante comparação com este culto moderno que não foi bem documentado até 0 presente.

O papel das águas cársticas é lembrado também por McNatt (1996), ao estudar os Maias do Belize e por Burri (2007), ao escrever sobre as águas cársticas no mundo antigo como objeto sagrado e recurso natural.

McNatt (1996) afirma que, geralmente, os Maias acreditavam que as cavernas e alguns corpos d'água eram a entrada para o mundo subterrâneo conhecido como Xibalba. Esse mundo era habitado por inúmeras deidades que representavam a morte, a doença, a velhice, o sacrifício, etc. As almas dos mortos precisavam passar por 9 níveis em Xibalba, sofrendo numerosas provações de sabedoria e coragem. Para eles, o próprio Sol completaria tal jornada a cada noite, assumindo a forma do deus Jaguar do subterrâneo (underworld). Para esse povo, as cavernas também possuíam um aspecto muito contrastante e positivo como fonte de nuvens, chuva, trovões e raios, sendo associadas à vida, à fertilidade e ao renascimento. No mundo Maia não eram consideradas simples feições naturais, mas sim, manifestações vivas do poder espiritual. Associadas com importantes ciclos tanto da vida como da morte, eram lugares logicamente adequados para rituais e cerimônias.

No México, Tate (2006) lembra que em Chalcatzingo, cerca de $90 \mathrm{~km}$ ao sudeste da Cidade do México, pesquisadores identificaram uma caverna que 
desempenhava um importante papel como centro religioso Olmeca dedicado à Deusa da Água.

Já Burri (2007) destaca a sacralidade e importância da água subterrânea na Antiguidade. O primeiro exemplo citado pelo autor é a oferta de moedas no século IV e V no interior da Gruta do Cervo (Grotta del Cervo) em Abruzzo, leste de Roma e depois, os exemplos de cavernas-igreja onde a água que surge do teto ou das paredes são tocadas e até coletadas pelos cristãos.

Nos exemplos citados, observa-se que tais cavernas ou santuários são, para o crente, o "centro do mundo" (ELIADE, 2002, p. 302) onde as tradições e as crenças são propagadas ao longo de séculos.

Aqui, destaca-se a importância do trabalho de Clendenon (2009a) que lida com o conceito de hidromitologia. O termo pode ser traduzido como o estudo das lendas e mitos que, historicamente, podem explicar as características naturais das águas cársticas em termos não científicos. A autora observa também o aumento da procura dos cientistas por histórias mitológicas que podem fornecer importantes informações sobre a história dos desastres naturais, por exemplo.

\section{O CARSTE E AS CAVERNAS DE IMPORTÂNCIA CULTURAL}

Para se ter uma ideia inicial da importância dos estudos culturais nas áreas cársticas é importante identificar um projeto, na União Europeia, realizado em parceria entre o Museu de História Natural e Arqueologia de Montebulla (Itália), o Instituto de Pesquisas do Carste (Eslovênia), o Notranjski Muzej (Eslovênia), a Universidade de Padova (Itália) e a Universidade de NiceSophie-Antipolis (França). O projeto recebeu o nome de Karstic Cultural Landscape: Architecture of a unique relationship people/territory.

Além de descrever três distintas paisagens europeias na Itália, Eslovênia e França (Montello, Udin boršt e Méailles, respectivamente), o projeto teve como objetivo envolver o máximo possível as instituições responsáveis pelo desenvolvimento cultural dessas regiões: museus, universidades e escolas. 0 resultado dessa interação foi a publicação de três volumes que abordaram 
aspectos culturais, geológicos, geomorfológicos, pedológicos, de uso e ocupação do solo, entre outros. Nos três volumes, cavernas de importância cultural foram identificadas.

Johnston (1985) afirma que a paisagem é constantemente modificada pelas ações humanas. Assim, considera que o meio físico, lugar onde as atividades humanas ocorrem, surge como um produto de uma série de processos que, continuamente, o modifica pelas sociedades. Assim, tais "paisagens culturais" são produzidas principalmente pela língua e pela religião.

No carste, o papel da língua é visível pela perpetuação das lendas e tradições orais e, no caso da religião, pela transformação das cavernas ou regiões próximas em lugares sagrados. Embora as origens dos motivos específicos que fazem um grupo se utilizar de uma caverna para fins religiosos não seja sempre fácil de identificar, Johnston (1985) afirma que a universalidade dos conjuntos de crenças e atividades associadas à religião sugere que isso seja uma necessidade humana básica. Tais atividades geram um conjunto de regras morais e éticas que influenciam significativamente vários aspectos do comportamento humano.

A importância cultural das paisagens cársticas é demonstrada pela IUCN-International Union for Conservation of Nature, ou União Internacional para a Conservação da Natureza, quando edita uma importante publicação sobre a situação atual e as proposições futuras para o manejo de áreas cársticas inscritas na lista do Patrimônio Cultural Mundial da UNESCO.

Sendo assim, levando em consideração tais componentes, é possível realizar um inventário que identifique possíveis Locais de Interesse Geomorfológico (LIGeom) definidos por Pereira (2006), adaptado para o carste por Forte (2008) e utilizado para a realidade brasileira por TRavassos (2010).

Atualmente, cerca de 45 Patrimônios Culturais da UNESCO apresentam importantes feições ou sistemas cársticos de significância internacional e sua distribuição espacial pode ser vista em um mapa elaborado em Williams (2008). Ainda assim, o valor cultural das paisagens cársticas não é identificado em sua totalidade como paisagens que foram elaboradas pela ação da natureza e do homem. Apenas 7 dos 45 sítios identificados por Williams (2008) 
apresentam os critérios culturais $i$ a vi propostos pelas diretrizes da UNESCO (2008). No mesmo documento, afirma-se que a 6a Sessão Extraordinária do Comitê do Patrimônio Cultural decidiu unir os dez critérios e não separá-los mais em culturais e naturais.

\section{EXEMPLOS MUNDIAIS E NACIONAIS}

A UNESCO considera que existem 878 sítios incluídos na Lista do Patrimônio Cultural Mundial que fazem parte do patrimônio cultural e natural. Esses possuem consideráveis valores universais. Em cerca de 145 países, deste total de sítios, 679 são culturais, 174 naturais e 25 possuem as duas variáveis simultaneamente. Em novembro de 2007, 185 países ratificaram a Convenção do Patrimônio Cultural Mundial.

Por esse motivo, para o trabalho, além do estudo das 45 regiões identificadas por Williams (2008), foram estudados outros sítios de importância cultural incluídos pela UNESCO e por Hayes (2005-2009). A autora reuniu mais de 1.100 sítios considerados sagrados em cerca 55 países. Muitos deles são cavernas-santuário. Tais sítios identificados não possuem, necessariamente, os três componentes propostos por Williams (2008), mas destacam-se no cenário do turismo cultural por possuírem forte ligação com o imaginário (e.g.: águas sagradas, cavernas sagradas, cavernas da mitologia, personagens bíblicas, etc). A partir deste momento, o autor do trabalho buscou outras informações orais e bibliográficas junto a diversos pesquisadores, bem como na literatura disponível.

Sabe-se da difícil tarefa de tentar delimitar o vasto campo dos estudos culturais do carste e das cavernas em poucas páginas. Por esse motivo, serão apresentados neste trabalho alguns dos exemplos brasileiros e internacionais mais significativos na opinião do autor. Tal valor de importância foi atribuído quando da consulta às inúmeras obras reunidas nas referências do trabalho. Tentou-se identificar exemplos por continente de acordo com registros históricos e científicos, bem como da proximidade do pesquisador com alguns destes lugares. Devido à vasta quantidade de pesquisas na Europa, será 
possível observar um maior número de exemplos do "Velho Mundo" como vistos em Travassos (2010).

Numerosos também são os exemplos de cavernas sagradas na América Central e no Brasil. Em muitas cavernas e sítios próximos a elas, é possível constatar que inúmeros vestígios do homem primitivo já foram encontrados, indo desde pontas de flecha e instrumentos de pedra à cinzas de fogueiras. Entretanto, o uso ritual desses ambientes ainda é pouco divulgado. Por essa razão, buscou-se demonstrar, também, com alguns exemplos por macroregião, achados arqueológicos que já assinalavam para um tipo de uso sagrado do ambiente cavernícola pelo mundo.

\section{AS PEREGRINAÇÕES NO CARSTE}

As peregrinações ou romarias a lugares considerados sagrados são um dos mais conhecidos fenômenos culturais e existem em várias sociedades. Assim, juntamente com o turismo religioso, tais fluxos de pessoas podem ser identificados no Cristianismo, no Budismo, no Hinduísmo, no Judaísmo e no Islamismo.

Para Paiva (2007, p.184), a religião é um fenômeno mundial que sempre atraiu a atenção dos pesquisadores, "independentemente do objetivo pessoal de demonstrar a validade ou não da religião". O termo "religião", por si só, inclui as concepções, as atribuições e as histórias relacionadas com Deus ou com os deuses; engloba sentimentos, afetos e emoções relacionadas a essas entidades e, por último, apresenta lugares, ações, práticas e rituais relativos a concepções e emoções (PAIVA, 2007)

Principalmente por esses motivos que o homem religioso dá início às peregrinações. Barber (1993) define a peregrinação como uma jornada motivada pela crença religiosa. Manifesta-se externamente em direção a um sítio sagrado e, internamente, por razões espirituais e de conhecimento interior. Para Gibson (2008) é possível entender essa manifestação como uma visita a um lugar santo que busca a certificação de onde ocorreram os fatos religiosos históricos. 
Muito já foi escrito sobre a relação entre as peregrinações, a geografia e o turismo, no entanto, ainda são poucos os registros que tratam das peregrinações a cavernas consideradas sagradas. Gibson (2004) afirma que a "Terra Santa", que testemunhou o nascimento, a vida, a crucificação e a ressurreição de Jesus, assim como outros eventos bíblicos, é destino conhecido de milhões de fiéis todos os anos. Em Jerusalém, a descoberta da Tumba de Jesus resultou na construção de uma basílica que faz parte da lgreja do Santo Sepulcro. Em Belém, têm-se a Igreja da Natividade, construída sobre a Gruta da Natividade.

Nos trabalhos que tratam das peregrinações ou romarias às cavernas, é possível observar certo grau de uniformidade entre as crenças dos peregrinos e dos turistas, mesmo que sejam de diferentes religiões. Talvez por essa razão as peregrinações sejam consideradas por muitos como um fenômeno que passa por diferentes religiões e culturas com uma série de padrões e conceitos similares.

Essa afirmação pode ser verificada ao se observar romarias ou visitações a cavernas consideradas sagradas. Para muitos, tais espaços possuem formas que são o testemunho da força divina. Suas águas, geralmente, são consideradas sagradas e a profanação deste local sagrado pode significar a punição. Mais recentemente, tais comportamentos mais ou menos uniformes têm chamado atenção dos pesquisadores, especialmente geógrafos, da Geografia da Religião, ou da Geografia Cultural.

Se as cavernas sempre atraíram a atenção do homem, a relação entre espaço e cultura pode ser considerada "uma tradição da ciência geográfica, haja vista que seus interesses sempre estiveram voltados para a exploração e descrição da diversidade da superfície da Terra" (CORRÊA, 2000, p. 48). Assim, para Claval (1997), devemos associar a Geografia Cultural à experiência que o ser humano tem com a natureza e o ambiente para, então, estudar "a maneira pela qual eles os modelam para responder às suas necessidades, seus gostos e suas aspirações" (CLAVAL, 1997, p. 89).

Aplicando os conceitos da Geografia Cultural, é possível buscar compreender como os lugares são construídos, especialmente no caso das 
cavernas de uso cultural/religioso. Sendo assim, acredita-se que tais pesquisas devam ser orientadas para a interdisciplinaridade e não somente para um único ramo do conhecimento.

Como lembrado por diversos autores, o ato de peregrinar é motivado pelas ideias de fé e sacrifício presentes na origem do ato religioso (OLIVEIRA, 2004). Assim, pode-se dizer que a busca por cavernas que estejam em posições elevadas no terreno ou que proporcionem algum tipo de esforço ou sacrifício para visitá-las não é uma mera coincidência. Neste caso, além do óbvio sacrifício físico, é possível identificar, no nível pessoal, até mesmo o sacrifício econômico ou o esforço individual de adentrar a escuridão da caverna e vencer os medos por estar, agora, protegida pelo sagrado.

Igualmente importante é o fato de que não se deve confundir interesse pelas impressões da cultura nestes espaços, com a confissão religiosa. É interessante lembrar Vilhena (2003), citado por Oliveira (2004), que afirma ser o turismo religioso o turismo que não perdeu sua raiz peregrina, continuamente motivada pelo exercício místico da celebração.

Deve-se aplicar esse conceito à temática da pesquisa afirmando que 0 turismo religioso em cavernas, também com uma raiz antiga, é constantemente motivado pela vontade de vencer o medo da mística da escuridão dos "antigos portais do inferno da antiguidade" e na tentativa popular de se explicar fenômenos não explicáveis facilmente pelo leigo. Ainda, o turismo religioso em cavernas deve ser percebido como o resgate (mesmo que inconsciente), da ligação do ser humano com a "Mãe Terra".

Para satisfazer aqueles que se dedicam à causa ambientalista, lembramos Oliveira (2004) quando afirma ser preciso que o turismo contemporâneo seja tratado como um vetor de desenvolvimento ambiental, social, cultural e econômico tendo, inclusive, um papel educativo.

\section{CONSIDERAÇÕES FINAIS}

O presente trabalho teve a intenção de chamar a atenção para o uso cultural das cavernas sob a ótica do uso ritualístico e religioso. Tentou-se 
também, evidenciar como tais práticas realizadas no subterrâneo apresentam características similares em diversas culturas. Tentou-se, em poucas páginas, identificar o uso do carste e das cavernas a partir da análise de trabalhos de geógrafos clássicos da Escola Alemã e Francesa, bem como a identificação de trabalhos mais recentes que demonstram 0 uso cultural religioso do subterrâneo. Estudos de caso foram realizados com o objetivo de ilustrar os conceitos trabalhados inicialmente e buscou-se focar as cavernas como o "centro do mundo" religioso para romeiros. Por esse motivo, a carstologia e a espeleologia, assim como a geografia devem ser consideradas ciências plurais; não totalmente físicas nem totalmente humanas.

Não foi o objetivo do trabalho generalizar o fenômeno mundial do uso religioso das cavernas e sim, identificar seus pontos de convergência em relação aos conceitos trabalhados especialmente na Geografia Cultural e, mais especificamente, na Geografia da Religião. Observou-se uma vasta distribuição espacial das cavernas consideradas sagradas, porém, com fatos similares em relação à sua sacralização, posição em relação ao terreno, posição central em uma região e pólo de convergência de pessoas.

Embora os estudos acadêmicos da Geografia da Religião associado às cavernas sejam relativamente novos, vários autores destacam que o interesse pela dimensão religiosa da Geografia é bem mais antigo. Originaram-se na Antiguidade Clássica, seguido de estudos de Vidal de La Blache e da Geografia Cultural de Sauer, do início do século XX, até os anos 1960.

Mais recentemente Forti (2009) lembra que as Ciências Sociais, especialmente a Teologia, passaram a se interessar mais profundamente pelas cavernas. A maioria das religiões considera o subterrâneo como lugares sagrados que proporcionam a vida ou, também como locais profanos que precisam ser sacralizados. Deixando de lado a dimensão religiosa Forti (2009) também afirma que o subterrâneo possui um importante papel social nas estórias de um grupo social.

Nos sítios pesquisados e visitados, observou-se a possibilidade de estudo de todos os temários que puderam ser constatados ao longo do desenvolvimento do trabalho. Os espaços das cavernas de uso religioso se 
transformaram em lugares sagrados pela fé, ao longo dos anos. Transformaram-se, pela tradição, em centros de convergência de fluxos de peregrinos, turistas e capital.

Merece destaque o fato de que o patrimônio cultural da paisagem cárstica tem se tornado objeto de interesse da comunidade científica internacional e nacional, embora, ainda existam poucos trabalhos que abordem a temática no Brasil. Igualmente recentes são os trabalhos que apresentam a importância cultural do carste e das cavernas. Por essa razão, no país, são ainda mais escassos os trabalhos que visam a inventariação de geomorfosítios, que apresentem significativas qualidades físicas e humanas (culturais).

Aplicando tal afirmação para as áreas cársticas brasileiras e eslovenas e o uso religioso de cavernas, sua inventariação e quantificação como possíveis geomorfosítios é praticamente nula e Travassos (2010) fornece uma primeira abordagem para trabalhos futuros. As questões que foram tratadas no artigo, de maneira resumida, devem ser vistas como uma contribuição para a Geografia e a Carstologia.

Se Silva (2002) afirma que os estudos humanísticos estão voltados para as relações que os indivíduos estabelecem entre si, os sentimentos, as percepções e as atitudes do ser humano sobre o espaço e o lugar a partir da experiência vivida, o presente artigo é apresentado como uma contribuição no ramo da geografia, da carstologia e da espeleologia nacionais ao trabalhar a relação humana com as cavernas.

Se Abreu et al. (2003), citados por Forte (2008, p.32), consideram as cavidades naturais subterrâneas como o "parente pobre do património geomorfológico", para a realidade brasileira e, talvez, internacional, é possível dizer que as cavernas de uso cultural e religioso são aquelas que normalmente vivem à margem da comunidade científica. Acredita-se que seja necessária uma mudança de postura em relação a isso.

Faz-se, então, necessário lembrar novamente dos inúmeros exemplos de cavernas que foram objetos de cultos pré-históricos e proto-históricos. Nelas, acredita-se que o homem primitivo realizava rituais "mágicos", também se expressava através da arte e sepultava seus mortos nestes locais. Essas 
"impressões" humanas no espaço subterrâneo têm íntima relação com a geografia cultural e até mesmo compartilham do mesmo desenvolvimento tardio no país.

Para Travassos e Varela (2009), se levarmos em conta o princípio de que, no Brasil, o meio ambiente é um bem constitucionalmente protegido (art. $225 \mathrm{CF} / 88$ ), tais manifestações culturais e religiosas poderiam ser vistas como algo que deve ser reprimido. É justamente aí que o pesquisador deve ter uma compreensão mais aberta da realidade social, ou do que os intérpretes do Direito chamam de domínio normativo. Se, de um lado há a proteção ambiental, de outro, há a proteção da liberdade de crença que assegura o livre exercício dos cultos religiosos e garante, na forma da lei, a proteção desses locais e suas liturgias (art. 5ํ, $\mathrm{VI}$ da CF/88). Observa-se, assim, a proteção de dois bens que na teoria não se conflitam, mas que na prática podem entrar em choque.

Dessa forma, considera-se que a proteção ora do meio ambiente ora da liberdade de crença depende da situação fática que, para os intérpretes do Direito Constitucional, significa que, nos casos de conflitos de bens protegidos constitucionalmente deve-se levar em consideração o princípio da concordância prática ou da harmonização. Para Canotilho (2003), citado por Travassos e Varela (2009), tal princípio preconiza a coordenação e combinação dos bens jurídicos em conflito, de forma a evitar o sacrifício total de uns em relação aos outros.

Defende-se que, no caso específico da proteção ambiental e da liberdade de crença, a sobreposição de um bem em relação ao outro deve ser analisada caso a caso. Em determinado espaço, onde são tradicionalmente realizadas manifestações religiosas, acredita-se que não deve prevalecer a proteção ambiental, pois aquele lugar adquiriu um valor social ao longo da história podendo, inclusive, ser manejado para o turismo.

Entretanto, deve haver um mínimo de proteção que não inviabilize a prática da fé. Já em espaços onde não exista a comprovação de prática tradicional histórica de manifestação religiosa, a proteção ambiental deve prevalecer. Caso o intérprete da lei não compreenda os processos históricos e 
sociais que o cercam, isso pode levá-lo a decidir de forma precipitada e equivocada pela prevalência absoluta de apenas um desses bens. O que os pesquisadores nunca podem se esquecer é da importância da variável humana em suas análises. Sendo assim, deve-se considerar a realidade social como a base fundamentadora de toda interpretação legal ou como orientação para qualquer pesquisa científica. Seu isolamento, geralmente, afasta tais atividades da aplicação prática coerente (TRAVASSOS \& VARELA, 2009).

Sob uma perspectiva histórica, vemos que cavernas (cársticas ou não) foram sacralizadas ao longo da história por hierofanias distintas, porém, com algumas similitudes. Nestes espaços, os turistas são atraídos por características estéticas, enquanto os peregrinos são atraídos por experiências pessoais e espirituais particulares. É interessante destacar, porém, que o "estético" buscado pelo simples turista é justamente ampliado pela "impressão", ao longo dos anos, das experiências pessoais e particulares dos peregrinos que vieram atuando de forma coletiva no espaço.

Acredita-se, também, que o turismo religioso possa funcionar como uma experiência educativa. Sendo assim, se o turismo cultural e religioso for bem orientado, peregrinos e turistas serão capazes de aprender algo além dos rituais. Devido ao fato do Brasil possuir a língua em comum com Portugal e ter sido sua colônia desde o século XVI ao século XIX, a palavra Lapa é utilizada para designar uma rocha, abrigo sob rocha ou caverna. Embora o país tenha sido formado a partir da mistura de grupos indígenas, do branco colonizador e do africano escravizado, o catolicismo ainda era muito forte entre a população da colônia, que possuía forte contato com as tradições religiosas ibéricas.

Acreditamos que, mesmo que o uso de cavernas para fins religiosos provoque inúmeros impactos ambientais negativos, a sua importância cultural é enorme. Não é possível admitir a simples proibição dos cultos, pois as crenças religiosas geralmente têm um impacto positivo sobre a economia regional e na qualidade de vida do romeiro. Devem-se buscar, portanto, estratégias de mitigação dos impactos para a valorização do patrimônio desses sítios e desencorajar o uso de outras cavernas para este fim. 
Tanto na Europa quanto no Brasil e em outras partes do mundo, as cavernas têm sido utilizadas como abrigos em tempo de guerra e como santuários, entre tantas outras formas de utilização. Muitas das cavernas santuário (não tão numerosas em relação ao número de cavernas registradas), encontram-se impactadas (ou mesmo "sacrificadas") mas, dificilmente serão deixadas para a prática em outras cavernas. Uma vez sacralizadas, tendo experienciado supostas hierofanias, a tradição resistirá por séculos, reduzindo a maioria dos impactos nessas áreas. Esses serão ou não minimizados de acordo com a elaboração de estratégias de educação ambiental.

Dessa forma, acreditamos que cavernas-igreja (ou cavernas-templo) devam continuar a existir, pois não afetam gravemente o patrimônio espeleológico como um todo. No Brasil, das quase 5.000 cavernas conhecidas pouquíssimas podem ser consideradas de uso religioso. Citando um exemplo europeu, das quase 9.000 cavernas da Eslovênia, poucas também foram ou são utilizadas para fins religiosos. Nesse país, o patrono da água subterrânea é St. Canzian e muitas igrejas foram construídas próximas a fontes de água. Não seria essa uma boa oportunidade para a proteção do recurso? Portanto, acreditamos que intervenções no sentido de simplesmente proibir ou forçar uma disciplina que vai contra séculos de tradição não seria o mais apropriado e, sobretudo, não seria o mais eficiente.

O que devemos buscar é o diálogo com os diversos atores sociais envolvidos e desencorajar o uso de outras cavernas para esse fim. Isso nos parece o mais correto e também o mais simples, pois como já dito, quando um espaço se torna um lugar sagrado, a "migração" para outros dificilmente ocorre. Tomemos como exemplo Bom Jesus da Lapa, que é utilizada como Igreja desde 1691, e a Gruta de Lourdes na França, desde 1854, entre outros inúmeros templos pelo mundo. Assim, percebe-se que uma característica comum a muitos sítios sagrados é que são percebidos como o centro da atividade cultural e do destino dos peregrinos.

Deve-se, portanto, buscar o aprimoramento dos estudos sobre o carste nacional para que se possa caminhar rumo à melhoria da qualidade ambiental 
destes sistemas naturais complexos, contribuindo, consequentemente, para a melhoria da qualidade de vida das sociedades.

\section{AGRADECIMENTOS}

Minhas pesquisas contaram com a colaboração direta ou indireta de diferentes instituições e de vários profissionais e amigos os quais sou grato.

Em especial, agradeço ao meu orientador de Mestrado, Prof. Dr. Heinz Charles Kohler, por seus ensinamentos a respeito do carste e por sua amizade e confiança em meu trabalho desde o momento em que começamos nossa jornada acadêmica.

Ao Prof. Dr. Oswaldo Bueno Amorim Filho meus agradecimentos pelos constantes ensinamentos e aconselhamentos profissionais, bem como por sua amizade. Já Ihe disse uma vez e gostaria de tornar público que, se Humboldt é o pai da Geografia, certamente considero o Prof. Oswaldo como o pai da "minha Geografia"; da Geografia plural; da Geografia que assim como a Carstologia, deve sempre buscar a integração de conhecimentos dos diversos ramos de atuação.

Ao meu mentor Esloveno, Dr. Andrej Kranjc, do Instituto de Pesquisas do Carste da Eslovênia os meus sinceros agradecimentos e o reconhecimento pelas oportunidades que me foram dadas, os conhecimentos sempre compartilhados e, acima de tudo, por sua grande amizade. Seu auxílio e apoio foram fundamentais na conclusão desta tese e, especialmente na minha formação como Carstólogo.

À sua esposa Maja Kranjc, bibliotecária do Instituto de Pesquisas do Carste, acredito que minhas palavras aqui não sejam suficientes para expressar sua atenção, sua dedicação e seu empenho em me auxiliar sempre que precisei "garimpar" preciosas obras da biblioteca. Ressalto também que, muitas das vezes, essa ajuda veio de sua própria iniciativa. Por isso e tantas outras coisas, sou extremamente grato. 


\section{REFERÊNCIAS}

AMORIM FILHO, O.B. Estudos Orientados. Belo Horizonte: PUC Minas, 2008. Notas.

AMORIM FILHO, O.B. A Pluralidade da Geografia e as Abordagens Humanistas/Culturais. In: COLÓQUIO NACIONAL DO NÚCLEO DE ESTUDOS EM ESPAÇO E REPRESENTAÇÕES, 1, 2007. Anais... São Paulo: USP, 2007. 1CD-ROOM.

AMORIM FILHO, O. B. As Geografias Universais e a passagem do milênio. Revista Geografia e Ensino, Belo Horizonte, v.3, n.9, p.19-34, 1988.

ANTONOV, G. Sacred caves in Strandža Mountains, S.E. Bulgaria. In: $7^{\text {th }}$ International Speleological Congress, Sheffield, 1977.

AULER, A.; RUBBIOLI, E.; BRANDI, R. As grandes cavernas do Brasil. Belo Horizonte: GBMP, 2001.

AULER, A. Karst areas in Brazil and the potential for major caves: an overview. Bol.Soc.Venezolana Espel., Caracas, v.35, p.1-18, 2002.

BARBER, R. Pilgrimages. London: The Boydell Press, 1993.

BARBOSA, E. P. Cavernas, estórias, história e tradições religiosas no interior da Bahia. In: SIMPÓSIO ANUAL DA ASSOCIAÇÃO BRASILEIRA DE HISTÓRIA DAS RELIGIÕES - ABHR, 4, 2007, Viçosa. Anais... Viçosa: ABHR, 2007.

BARBOSA, E.P.; TRAVASSOS, L.E.P. Caves, stories, history and popular traditions in the semi-desert (Sertão) of Bahia, northeastern Brazil. Acta Carsologica, v. 37, n.2-3, p. 331-338, 2008.

BERGER, E. Sherpa Buddhists on a regional pilgrimage: the case of Maratika Cave at Halase. Occasional papers in Sociology and Anthropology, v.4, p.124145, 1994.

BÍBLIA SAGRADA. Versão dos Monges de Maredsous (Bélgica) traduzida para o português pelo Centro Bíblico Católico, revisão Frei João José Pereira de Castro. São Paulo, Ave Maria / Parma, 1959. 1632 p.

BRITO, A.G. As montanhas e suas representações: buscando significados a luz da relação Homem-Natureza. Revista de Biologia e Ciências da Terra, v.8, n.1, p.1- 20, 2008.

CAILLOIS, R. O homem e o sagrado (1939). Lisboa: Edições 70, 1988.

CASCUDO, L. da C. Geografia dos Mitos Brasileiros. São Paulo: Global, 2002.

CASCUDO, L. da C. Dicionário do folclore brasileiro. Revisto, atualizado e ilustrado. 10.ed. São Paulo: Global, 2001.

CLARK, I.D. The abode of malevolent spirits and creatures - Caves in Victorian Aboriginal social organization. Helictite, v.40, n.1, p. 2-10, 2007. 
CLAVAL, P. As abordagens da geografia cultural. In: CASTRO, I.E. de; GOMES, P.C. da C.; CORRÊA, R. L. (Org.). Explorações Geográficas. Rio de Janeiro: Bertrand Brasil, 1997.

CLENDENON, C. Karst hydrology in ancient myths from Arcadia and Argolis, Greece. Acta Carsologica, v.38, n.1, p.145-154, 2009a.

CLENDENON, C. Hydromythology and the Ancient Greek World: An Earth Science Perspective Emphasizing Karst Hydrology. Michigan: Fineline Science Press, 2009b.

ČUK, A. Postojna Cave. Postojna: Turizem Kras, destinacijski management, 2008.

CORRÊA, M.M. da S. A pós-modernidade e as atuais orientações da geografia humana. Boletim Goiano de Geografia, v.20, n.1-2, p.43-76, 2000.

CRESSWELL, T. Place. In: WARF, B. (Ed.) Encyclopedia of Human Geography. London: SAGE Publications, 2006. p. 356-358.

DAY, M.J. Military Campaigns in Tropical Karst Terrain: The Maroon Wars of Jamaica. In: CALDWELL, D.; EHLEN, J.; HARMON, R. (Eds.) Studies in Military Geology and Geography. Netherlands: Springer, 2004. p.79-88.

DIENER, P. The picturesque as an aesthetic category in the art of travelers: notes on J. M. Rugendas's work. Historia (Santiago), Santiago, v.3, Selected Edition, 2007.

ELIADE, M. Tratado de história das religiões. 2.ed. São Paulo: Martins Fontes, 2002.

ELIADE, M. Mito e realidade (1963). 4.ed. São Paulo: Perspectiva, 1994.

ELIADE, M. O sagrado e o profano (1956). São Paulo: Martins Fontes, 1996.

ELIADE, M. O sagrado e o profano (1956). São Paulo: Martins Fontes, 1992.

ELIADE, M. Imagens e símbolos: ensaios sobre o simbolismo mágico-religioso. São Paulo: M. Fontes, 1991.

ELIADE, M. The Encyclopedia of Religion, vol.12, "Sacred Space" (MacMillan Reference Books: London, 1987.

ELIADE, M. História das crenças e das idéias religiosas. 2.ed. Rio de Janeiro: Zahar, 1983 3v. (Espírito e matéria)

EVIA CERVANTES, C.A. El mito de la serpiente tsukán. Mérida/Yucatán: Universidad Autónoma de Yucatán, 2007.

EVIA CERVANTES, C.A. Selección de mitos. Mérida/México: Universidad Autónoma de Mexico (UADY), 2006.

FERENC, M. Prikrito in očem zakrito: prikrita grobišča 60 let po koncu druge svetovne vojne. Celje: Muzej novejše zgodovine, 2005.

FIGUEIREDO, L. A. V. de. O imaginário, o simbólico e as cavernas: estudos preliminares. In: CONGRESSO BRASILEIRO DE ESPELEOLOGIA, 25, 1999, 
Vinhedo. Anais... Vinhedo-SP: Trupe Vertical/SBE/Prefeitura Municipal de Vinhedo, 1999. p.165-171.

FIGUEIREDO, L. A. V. de. Imaginary and representations of caves: a case study of residents in urban centers and rural karstic areas of São Paulo (Brazil). In: INTERNATIONAL CONGRESS OF SPELEOLOGY,13, SPELEOLOGICAL CONGRESS OF LATIN AMÉRICA AND CARIBBEAN, 4, BRAZILIAN CONGRESS OF SPELEOLOGY, 26, 2001. Anais... Brasília-DF: Sociedade Brasileira de Espeleologia, 2001. 1 CD-ROM.

FIGUEIREDO, L. A. V. de.; TRAVASSOS, L.E.P.; SILVA, A.S. da. A CAVERNA NO CINEMA: análise preliminar de paisagens naturais e simbólicas. In: CONGRESSO BRASILEIRO DE ESPELEOLOGIA, 30, 2009. Montes Claros. Anais... Montes Claros: SBE, 2009.

FORD, D.C. Jovan Cvijić and the founding of karst geomorphology. Environmental Geology, v.51, n.5, p.675-684, Jan. 2007.

FORD, D.C.; WILLIAMS, P.W. Karst Hydrogeology and Geomorphology. Wiley: Chichester, 2007.

FORTI, P. State of art in the Speleological Sciences. In: INTERNATIONAL CONGRESS OF SPELEOLOGY, 15, 2009. Proceedings... UIS/NSS: Texas, 2009. p.26-31. Volume 1.

FORTE, J.P. Avaliação do património geomorfológico na Unidade Territorial de Alvaiázere. 2008. 328f. Dissertação (Mestrado) - Programa de Pós-graduação em Geografia Física - Recursos e Riscos Ambientais. Universidade de Lisboa.

GALIMBERTI, U. Rastros do sagrado: o cristianismo e a dessacralização do sagrado. São Paulo: Paulus, 2003.

GAUCHON, C. Des cavernes e dês hommes: geographie souterraine dês montagnes françaises. Karstologia, mémoires n.7, 1997.

GAUCHON, C. Les Grottes Sanctuaires dans le sud-est de La France. Karstologia, n.19, p. 11-22, 1 Semestre 1992

GIBSON, S. A Gruta de São João Batista: A primeira prova arqueológica da veracidade dos evangelhos. Rio de Janeiro: Record, 2008.

GIBSON, S. The cave of John the Baptist: The Stunning Archaeological Discovery that has Redefined Christian History. New York: Doubleday, 2004.

GIL FILHO, S. F. Espaço Sagrado: estudos em geografia da Religião. Curitiba: Editora IBPEX, 2008.

GIL FILHO, S. F. Sobre a Geografia da religião. In: COLOQUIO NACIONAL DO NÚCLEO DE ESTUDOS EM ESPAÇO E REPRESENTAÇÕES, 1, 2007. Anais... Curitiba: NERR/UFPR, 2007a. 1 CD-ROM.

GILL FILHO, S.F. Geografia da Religião: reconstruções teóricas sob o idealismo crítico.In: COLÓQUIO NACIONAL DO NÚCLEO DE ESTUDOS EM ESPAÇO E REPRESENTAÇÕES, 1, 2007b. Anais... São Paulo: USP, 2007. $1 C D-R O O M$. 
GILL FILHO, S.F. Estruturas da territorialidade católica no Brasil. Scripta Nova, Barcelona, v.10, n.205, 2006, p. 741-798.

GIL FILHO, S. F. Geografia Cultural: Estrutura e Primado das Representações. Espaço e Cultura. Rio de Janeiro: NEPEC, v.19-20, p.51-59, 2005.

GIL FILHO, S. F. Por uma Geografia do Sagrado. In: MENDONÇA, F. \& KOEZEL, S. (org.) Elementos de Epistemologia da Geografia Contemporânea. Curitiba: Editora UFPR, 2002. p.253-265.

GIL FILHO, S. F. Por uma Geografia do Sagrado. RA'E GA O Espaço Geográfico em Análise, Curitiba, , v.5, p.67-78, 2001.

GOMES, P.F. A sociedade e a produção do imaginário no município de Santa Luzia. In: TEIXEIRA, M.G. O imaginário das grutas. Ilhéus, BA: UESC/CEDOC, 2003. p.47-70.

GUIMARÃES, R.L.; TRAVASSOS, L.E.P.; VARELA, I.D. Cavernas e rituais afro-brasileiros em Minas Gerais. In: TRAVASSOS, L.E.P.; MAGALHÃES, E.D.; BARBOSA, E.P. Cavernas, rituais e religião. Ilhéus/Bahia: Editus, 2009 (No prelo).

GUIMARÃES, R.L.; TRAVASSOS, L.E.P.; VARELA, I.D. Cavernas e Religião: A Gruta da Macumba em Lagoa Santa, Minas Gerais, Brasil.. In: XXIX Congresso Brasileiro de Espeleologia, 2007, Ouro Preto. Anais..., 2007. 1CDROM

GUTIÉRREZ LÓPEZ, J.M.; REINOS DEL RÍO, M.C.; GILES PACHECO, F.; FINLAYSON, C.; SANTIAGO PÉREZ, A. Gorham (Gibraltar): uma cueva santuário durante la antigüedad. Boletín Sedeck, n.2, p.16-20, 2001.

HÅLAND, E. J. Water sources and the sacred in modern and ancient Greece and Beyond. Water History, v.1, n.1, pp. 1-26

HAMILTON-SMITH, E. Karst and World Heritage Status, Acta Carsologica, v.36, n.2, p.291-302, 2007.

HAMILTON-SMITH, E. Wilderness Myths and Australian Caves, Helictite, v.25, n.2, p.68-73, 1987.

HASSNER, R. E. Understanding and resolving disputes over sacred space. Stanford Center on Conflict and Negotiation, Stanford University: Palo Alto, 2002.

HAYES, H. Sacred Destinations, 2005-2009. Disponível em: <http://www.sacred-destinations.com> Acesso em 15 Fev 2008.

HENRIQUES, R.P.B. A viagem que revelou a biodiversidade. Ciência Hoje, v.42, n.252, p. 24-29, Setembro 2008.

HOELSCHER, S. Topophilia. In: WARF, B. (Ed.) Encyclopedia of Human Geography. London: SAGE Publications, 2006. p. 495.

HUMBOLDT, A.V. COSMOS: a sketch if a physical description of the Universe by Alexander Von Humboldt (1858). Translated from the German by E.C. Otté and William Sweetland Dallas. London: Bell \& Daldy, 1865. v.5. 
HUMBOLDT, A.V. COSMOS: a sketch if a physical description of the Universe by Alexander Von Humboldt. Translated from the German by E.C. Otté. New York: Harper \& Brothers Publishers, 1856a. v.1.

HUMBOLDT, A.V. The Island of Cuba: a political essay. Translated from the Spanish with notes and preliminary essays by J.S. Thrasher. New York: Derby \& Jackson, 1856b.

HUMBOLDT, A.V. Personal Narratives of travels to the Equinoctial Regions of America during the years 1799 - 1804 by Alexander Von Humboldt and Aimé Bonpland Translated and Edited by Thomasina Ross. London: Henry G. Gohn, 1852a. v.1.

HUMBOLDT, A.V. Personal Narratives of travels to the Equinoctial Regions of America during the years 1799 - 1804 by Alexander Von Humboldt and Aimé Bonpland. Translated and Edited by Thomasina Ross. London: Henry G. Gohn, 1852b. v.2.

HUMBOLDT, A.V. Views of nature: or contemplations on the sublime phenomena of creation. Translated from German by E.C. Otté e Henry G. Hohn. London: Henry G. Gohn, 1850.

HUMBOLDT, A.V. Personal Narratives of travels to the Equinoctial Regions of America during the years 1799 - 1804 by Alexander Von Humboldt and Aimé Bonpland. Translated from French by Helen Maria Williams. London: Longman, Hurst, Rees, Orme, Brown and Green, 1829. v.7.

HUMBOLDT, A.V. Personal Narratives of travels to the Equinoctial Regions of America during the years 1799 - 1804 by Alexander Von Humboldt and Aimé Bonpland. Translated from French by Helen Maria Williams. London: Longman, Hurst, Rees, Orme, Brown and Green, 1827. v.5.

HUMBOLDT, A.V. A Geognostical Essay on the Superposition of Rocks in Both Hemispheres by Alexander von Humboldt. Translated from the original French. London: Longman, Hurst, Rees, Orme, Brown and Green, 1823.

HUMBOLDT, A.V. Political Essay on the Kingdom of New Spain by Alexander Von Humboldt. Translated from the original French by John Black. London: Longman, Hurst, Rees and Brown, 1822a. v.2-4.

HUMBOLDT, A.V. Personal Narratives of travels to the Equinoctial Regions of America during the years 1799 - 1804 by Alexander Von Humboldt and Aimé Bonpland. Translated from French by Helen Maria Williams. London: Longman, Hurst, Rees, Orme and Brown, 1822b. v.3.

HUMBOLDT, A.V. Personal Narratives of travels to the Equinoctial Regions of America during the years 1799 - 1804 by Alexander Von Humboldt and Aimé Bonpland. Translated from French by Helen Maria Williams. London: Longman, Hurst, Rees, Orme and Brown, 1819. v.4.

HUMBOLDT, A.V. Personal Narratives of travels to the Equinoctial Regions of America during the years 1799 - 1804 by Alexander Von Humboldt and Aimé Bonpland. Translated from French by Helen Maria Williams. London: Longman, Hurst, Rees, Orme and Brown, 1818. v.1 \& 2. 
HUMBOLDT, A.V. Personal Narratives of travels to the Equinoctial Regions of America during the years 1799 - 1804 by Alexander Von Humboldt and Aimé Bonpland. Translated from French by Helen Maria Williams. London: Longman, Hurst, Rees, Orme and Brown, 1814. v.1.

HUMBOLDT, A.V. Political Essay on the Kingdom of New Spain by Alexander Von Humboldt. Translated from the original French by John Black. New York: Riley, 1811. v.1.

INSTITUTO BRASILEIRO DE GEOGRAFIA E ESTATÍSTICA (IBGE). Censo Demográfico 2000, Rio de Janeiro: IBGE, 2010. Disponível em: <http://www.ibge. gov.br/ibgeteen/datas/religiao/brasil.html > Acesso em: 10 Mar 2010.

INSTITUTO SALESIANO SÃO CALLISTO. The Christian Catacombs of Rome, 2005. Disponível em: <http://www.catacombe.roma.it/index.html> Acesso em 12 de maio de 2007

JOHNSTON, R.S. To the ends of the Earth. In: JOHNSTON, R.S. The future of geography. London/New York: Methuen, 1985. p. 326-338.

KARMANN, I. Evolução e dinâmica atual do sistema cárstico do Alto Vale do Ribeira de lguape, sudoeste do estado de São Paulo. 1994. 228p. Tese (Doutorado) - Universidade de São Paulo.

KARMANN, I.; SALLUN FILHO, W. Paisagens subterrâneas do Brasil. Ciência Hoje, São Paulo, v.40, n. 235, p.18-25, 2007.

KEJONEN, A. On the oral folklore connected with caves in Finland. In: Internatinoal Congress of Speleology, 12, 1997, Switzerland. Proceedings... Switzerland: UIS, 1997. p.53-56.

KIERNAN, K. Religious sites. In: GUNN, J. (Ed.). Encyclopedia of caves and karst science. London: Routledge, 2003. p.622-625.

KIRCHER, A. Mundus subterraneus in XII libros digesus.... Tomus I. Amstelodami [Amsterdam]: Jansson Waesberg, 1678.

KOHLHEPP, G. Descobertas científicas da Expedição de Alexander von Humboldt na América Espanhola (1799-1804) sob ponto de vista geográfico. Revista de Biologia e Ciências da Terra, v.6, n.1, p. 260-278, 2006. Tradução de Luiz Eduardo Panisset Travassos.

KOZEL, S. As representações no geográfico. In: MENDONÇA, F.; KOZEL, S. (Org.) Elementos de Epistemologia da Geografia Contemporânea. Curitiba: E. UFPR, 2002, p.215-232.

KRANJC, A. Kras - Classical Karst (Slovenia-Italy) In: SIMPÓSIO NACIONAL DE GEOMORFOLOGIA/REGIONAL CONFERENCE ON GEOMORPHOLOGY, 6, 2006, Goiânia. Proceedings... Gôiania: IAG/UGB, 2006a. p.6.

KRANJC, A. About the name Kras (Karst) in Slovenia In: INTERNATIONAL CONGRESS OF SPELEOLOGY, 13, 2001, Brasília. Proceedings... Brasília: Sociedade Brasileira de Espeleologia/União Internacional de Espeleologia, 2001. 1 CD ROM. 
KRANJC, A. Introduction. In: KRANJC, A. (Ed.). KRAS: Slovene Classical Karst. Ljubljana: ZRC SAZU, 1997. p.07-17.

KRANJC, A. The beginnings of cave tourism in former hereditary lands of Carniola and (Lower) Styra. In: CAVES AND MAN, 1994. Procedings... Slovak Republic, 1994.

LASCU, C.; BACU, F.; GLIGAN, M.; SÂRBU, Ş. Cave Bear worship site in Peştera Rece, Bihor Moutains, Romania. Theoretical and Applied Karstology, v.7, p. 163-172, 1994.

LeBON, G. As opiniões e as crenças. São Paulo: Ícone, 2002. Livro VI, Cap. 1, p.195-201. Tradução de Antonio Roberto Bertelli (Coleção Fundamentos de Direito).

MALEČKAR, F. Šišca. Občinsko glasilo, v.8, n.9, p.12, 2005.

MALTE-BRUN, C. Universal Geography, or a description of all the parts of the World on a new plan according to the great natural divisions of the Globe; accompanied with analytical, syn optical, and elementary tables. Philadelphia: Published by John Laval, 1832. v.5.

MALTE-BRUN, C. Universal Geography, or a description of all the parts of the World on a new plan according to the great natural divisions of the Globe; accompanied with analytical, syn optical, and elementary tables. Boston: Lilly and Wait, (Late Wells and Lilly, 1831. v.8.

MALTE-BRUN, C. Universal Geography, or a description of all the parts of the World on a new plan according to the great natural divisions of the Globe; accompanied with analytical, syn optical, and elementary tables. Boston: Wells and Lilly, 1829. v.7.

MALTE-BRUN, C. Universal Geography, or a description of all the parts of the World on a new plan according to the great natural divisions of the Globe; accompanied with analytical, syn optical, and elementary tables. Boston: Wells and Lilly, 1828. v.6.

MALTE-BRUN, C. Universal Geography, or a description of all the parts of the World on a new plan according to the great natural divisions of the Globe; accompanied with analytical, syn optical, and elementary tables. Philadelphia: Published by Anthony Finley, 1827. v.1.

MALTE-BRUN, C. Universal Geography, or a description of all the parts of the World on a new plan according to the great natural divisions of the Globe; accompanied with analytical, syn optical, and elementary tables. Boston: Wells and Lilly, 1825a. v.3.

MALTE-BRUN, C. Universal Geography, or a description of all the parts of the World on a new plan according to the great natural divisions of the Globe; accompanied with analytical, syn optical, and elementary tables. Boston: Wells and Lilly, 1825b. v.4.

MALTE-BRUN, C. Universal Geography, or a description of all the parts of the World on a new plan according to the great natural divisions of the Globe; 
accompanied with analytical, syn optical, and elementary tables. Boston: Wells and Lilly, 1824. v.2.

McNATT, L. Cave archaeology of Belize. Journal of Caves and Karst Studies, v.58, n.2, p.81-99, 1996.

MENDES, S.R. O imaginário como objeto da história. In: TEIXEIRA, M.G. $O$ imaginário das grutas. Ilhéus, BA: UESC/CEDOC, 2003. p.71-107.

MIHEVC, Andrej. Use of the caves as mass graveyards in Slovenia. In: INTERNATIONAL CONGRESS OF SPELEOLOGY,13, SPELEOLOGICAL CONGRESS OF LATIN AMÉRICA AND CARIBBEAN, 4, BRAZILIAN CONGRESS OF SPELEOLOGY, 26, 2001. Anais... Brasília-DF: Sociedade Brasileira de Espeleologia, 2001. 1 CD-ROM.

MYLROIE, J.E.; CAREW, J.L.; CURRAN, H.A.; FREILE, D.; SEALEY, N.E.; VOEGELI, V.J. Geology of Cat Island, Bahamas: a Field trip guide. In: SYMPOSIUM ON THE GEOLOGY OF THE BAHAMAS AND OTHER CARBONATE REGIONS, 13, 2006. San Salvador/Bahamas: Gerace Research Center, 2006.

NEGEV, A.; GIBSON, S. Archaeological Encyclopedia of the Holy Land. London: Continuum, 2003.

NICOD, J. Les grottes: retrospective historique et insersion des grottesaménagées dans l'space geographic. Geographie, v.603, p. 508-530, 1998.

NICOD, J.; JULIAN, M.; ANTHONY, E. A historical review of man-karst relationships: miscellaneous uses of karst and their impacts. Revista Geografica Italiana, v.103, p.289-338, 1996.

OLIVEIRA, C.D.M. de. Turismo Religioso. São Paulo: Aleph, 2004. (Coleção ABC do Turismo).

PAIVA, G.J. de . Psicologia Cognitiva e Religião. Revista de Estudos da Religião, São Paulo, p.183-191, março 2007.

PEREIRA, P. Património geomorfológico: conceptualização, avaliação e divulgação. Aplicação ao Parque Natural de Montesinho. 2006. 370f. Tese (Doutorado) - Universidade do Minho, Braga. 2 mapas e 1 CD-Rom.

PILÓ, L.B. Ambientes Cársticos em Minas Gerais: valor, fragilidade e impactos ambientais decorrentes da atividade humana. O Carste, Belo Horizonte, v.11, n.3, p.50-58, 1999.

PILÓ, L.B. Morfologia cárstica e materiais constituintes: dinâmica e evolução da depressão poligonal Macacos-Baú, Carste de Lagoa Santa, MG. 1998. Tese (Doutorado) - Universidade de São Paulo

PILÓ, L.B. Rochas Carbonáticas e relevos cársticos em Minas Gerais. $O$ Carste, Belo Horizonte, v.9, n.3, p.72-78, 1997.

RAVBAR, N. The protection of Karst Waters: a comprehensive Slovene approach to vulnerability and contamination risk mapping. Postojna/Ljubliana: ZRC SAZU, 2007. 
RECLUS, E. The universal geography: earth and its inhabitants. Edited and translated by E.G. Ravenstein, F.R.G.S., F.S.S., Etc. London: J.S. Virtue \& Co. Limited, 1876-1894a. v.1 (Southern Europe - Greece, Turkey in Europe, Rumania, Servia. Italy, Spain and Portugal).

RECLUS, E. The universal geography: earth and its inhabitants. Edited and translated by E.G. Ravenstein, F.R.G.S., F.S.S., Etc. London: J.S. Virtue \& Co. Limited, 1876-1894b. v.2 (France and Switzerland).

RECLUS, E. The universal geography: earth and its inhabitants. Edited and translated by E.G. Ravenstein, F.R.G.S., F.S.S., Etc. London: J.S. Virtue \& Co. Limited, 1876-1894c. v.3 (Austria-Hungary, Germany, Belgium, and the Netherlands).

RECLUS, E. The universal geography: earth and its inhabitants. Edited and translated by E.G. Ravenstein, F.R.G.S., F.S.S., Etc. London: J.S. Virtue \& Co. Limited, 1876-1894d. v.4 (The British Isles).

RECLUS, E. The universal geography: earth and its inhabitants. Edited and translated by E.G. Ravenstein, F.R.G.S., F.S.S., Etc. London: J.S. Virtue \& Co. Limited, 1876-1894e. v.5 (The North-East Atlantic. Islands of the North Atlantic. Scandinavia. European Islands of the Arctic Ocean. Russia in Europe.).

RECLUS, E. The universal geography: earth and its inhabitants. Edited and translated by A. H. Keane, B.A., Memb. of Council, Anthropological Institute. London: J.S. Virtue \& Co. Limited, 1876-1894f. v.6 (Asiatic Russia).

RECLUS, E. The universal geography: earth and its inhabitants. Edited and translated by A. H. Keane, B.A., Memb. of Council, Anthropological Institute. London: J.S. Virtue \& Co. Limited, 1876-1894g. v.7 (East Asia).

RECLUS, E. The universal geography: earth and its inhabitants. Edited and translated By A. H. Keane, B.A. Memb. of Council, Anthrop. Institute; Cor. Memb. Italian Anthrop. Soc.; Professor of Hindustani, University Col. London; Author of "Asia", Etc. London: J.S. Virtue \& Co. Limited, 1876-1894h. v.8 (India and Indo-China).

RECLUS, E. The universal geography: earth and its inhabitants. Edited and translated by A. H. Keane, B.A. Memb. of Council, Anthrop. Institute; Cor. Memb. Italian Anthrop. Soc.; Professor of Hindustani, University Col. London; Author of "Asia", Etc. London: J.S. Virtue \& Co. Limited, 1876-1894i. v.9 (SouthWestern Asia).

RECLUS, E. The universal geography: earth and its inhabitants. Edited and translated by A. H. Keane, B.A. Memb. of Council, Anthrop. Institute; Cor. Memb. Italian Anthrop. Soc.; Professor of Hindustani, University Col. London; Author of "Asia", Etc. London: J.S. Virtue \& Co. Limited, 1876-1894j. v.10 (North-East Africa).

RECLUS, E. The universal geography: earth and its inhabitants. Edited and translated by A. H. Keane, B.A. Memb. of Council, Anthrop. Institute; Cor. Memb. Italian Anthrop. Soc.; Professor of Hindustani, University Col. London; Author of "Asia", Etc. London: J.S. Virtue \& Co. Limited, 1876-1894k. v.11 (North-West Africa). 
RECLUS, E. The universal geography: earth and its inhabitants. Edited and translated by A. H. Keane, B.A. Memb. of Council, Anthrop. Institute; Cor. Memb. Italian Anthrop. Soc.; Professor of Hindustani, University Col. London; Author of "Asia", Etc. London: J.S. Virtue \& Co. Limited, 1876-1894I. v.12 (West Africa).

RECLUS, E. The universal geography: earth and its inhabitants. Edited and translated by A. H. Keane, B.A. Memb. of Council, Anthrop. Institute; Cor. Memb. Italian Anthrop. Soc.; Professor of Hindustani, University Col. London; Author of "Asia", Etc. London: J.S. Virtue \& Co. Limited, 1876-1894m. v.13 (South and East Africa).

RECLUS, E. The universal geography: earth and its inhabitants. Edited and translated by A. H. Keane, B.A. Memb. of Council, Anthrop. Institute; Cor. Memb. Italian Anthrop. Soc.; Professor of Hindustani, University Col. London; Author of "Asia", Etc. London: J.S. Virtue \& Co. Limited, 1876-1894n. v.14 (Australasia).

RECLUS, E. The universal geography: earth and its inhabitants. Edited and translated by A. H. Keane, B.A. Memb. of Council, Anthrop. Institute; Cor. Memb. Italian Anthrop. Soc.; Professor of Hindustani, University Col. London; Author of "Asia", Etc. London: J.S. Virtue \& Co. Limited, 1876-18940. v.15 (North America).

RECLUS, E. The universal geography: earth and its inhabitants. Edited and translated by A. H. Keane, B.A. Memb. of Council, Anthrop. Institute; Cor. Memb. Italian Anthrop. Soc.; Professor of Hindustani, University Col. London; Author of "Asia", Etc. London: J.S. Virtue \& Co. Limited, 1876-1894p. v.16 (The United States).

RECLUS, E. The universal geography: earth and its inhabitants. Edited and translated by A. H. Keane, B.A. Memb. of Council, Anthrop. Institute; Cor. Memb. Italian Anthrop. Soc.; Professor of Hindustani, University Col. London; Author of "Asia", Etc. London: J.S. Virtue \& Co. Limited, 1876-1894q. v.17 (Mexico, Central America, West Indies).

RECLUS, E. The universal geography: earth and its inhabitants. Edited and translated by A. H. Keane, B.A. Memb. of Council, Anthrop. Institute; Cor. Memb. Italian Anthrop. Soc.; Professor of Hindustani, University Col. London; Author of "Asia", Etc. London: J.S. Virtue \& Co. Limited, 1876-1894r. v.18 (South America - The Andes Regions.).

RECLUS, E. The universal geography: earth and its inhabitants. Edited and translated by A. H. Keane, B.A. Memb. of Council, Anthrop. Institute; Cor. Memb. Italian Anthrop. Soc.; Professor of Hindustani, University Col. London; Author of "Asia", Etc. London: J.S. Virtue \& Co. Limited, 1876-1894s. v.19 (Amazonia and La Plata).

RODAWAY, P. Yi-Fu Tuan. In: HUBBARD, P.; KITCHIN, R.; VALENTINE, G. (Eds.) Key thinkers on Space and Place. 4.ed. London: SAGE Publications Ltd., 2007, p.306-310. 
ROLDAN, L.F.; WAHNFRIED, I.D.; KLEIN, D.A. Breve Abordagem Geológica das Províncias Espeleológicas do Brasil, 2003. Disponível em $<\mathrm{http}: / /$ www.redespeleo.org/espeleologia_geologia_provincias.php>. Acesso em 19 Dez. 2008

RONECKER, Jean-Paul. Simbolismo animal. São Paulo: Paulus Editora, 1997.

ROSENDAHL, Z. Representações do Sagrado: ratificando o domínio da emoção e do sentimento do ser-no-mundo. In: COLÓQUIO NACIONAL DO NÚCLEO DE ESTUDOS EM ESPAÇO E REPRESENTAÇÕES, 1, 2007. Anais... São Paulo: USP, 2007. 1CD-ROOM.

ROSENDAHL, Z. Espaço, Cultura e Religião: dimensões de análise. In: CORRÊA, R.L.; ROSENDAHL, Z. Introdução à geografia cultural. Rio de Janeiro: Betrand Brasil, 2003. p.187-224.

ROSENDAHL, Z. O Espaço, o Sagrado e o Profano. In: ROSENDAHL, Z.; CORREA, R.L.(Org.) Manifestações da Cultura no Espaço. Rio de Janeiro: UERJ, 1999.

ROSENDAHL, Z. Espaço e Religião: uma abordagem geográfica. Rio de Janeiro: UERJ, 1996.

SCHOBBENHAUS, C; BRITO NEVES, B.B. de. A geologia do Brasil no contexto da plataforma sul-americana. In: BIZZI, L.A.; SCHOBBENHAUS, C.; VIDOTTI, R.M.; GONÇALVES, J.H. (Ed.). Geologia, Tectônica e recursos minerais do Brasil: Textos, mapas e SIG. Brasília: CPRM, 2003. p.5-54.

SEGURA, T.V. Bom Jesus da Lapa. Resenha Histórica. São Paulo: Gráfica Ave Maria, 1937.

SEYMOUR, J.D. St. Patrick's Purgatory: a mediaeval pilgrimage in Ireland. Dundalk: W. Tempest, Publisher/Dundalgan Press, 1918.

SHAW, Trevor R. Names from the past in Postojnska Jama (Postojna Cave). Ljubljana: Založba ZRC/ZRC SAZU, 2006.

SILVA, C. A. da. O turismo no contexto da Geografia Humanística: espaço e lugar. Boletim Goiano de Geografia, v.22, n.2, p.73-92, jul./dez. 2002.

SILVA, D.C. Jacarandí - Vida e morte de um povoado. In: TEIXEIRA, M.G. O imaginário das grutas. Ilhéus, BA: UESC/CEDOC, 2003. p.29-46.

STAMENOVA, M. A.; ZHALOV, A. Some aspects of the protection of caves as a part of cultural heritage in Bulgaria . In: IV EUROPEAN SPELEOLOGICAL CONGRESS, Vercors, 2008, Lans-en-Vercors - Isère. Proceedings... Lans-enVercors - Isère: French Federation of Speleology/Speleological Federation of the European Union, 2008. p.234-236.

STEIL, C.A. O Sertão das Romarias: um estudo antropológico sobre o Santuáriode Bom Jesus da Lapa - Bahia. Petrópolis: Vozes/CID, 1996.

STEIL, C.A. Romeiros e turistas no Santuário de Bom Jesus da Lapa. Horizontes Antropológicos, Porto Alegre, v. 9, n. 20, p. 249-261, out. de 2003.

STEWARD, P.J. Myth and legends, caves in. In: CULVER, D.C.; WHITE, W.B (Ed.). Encyclopedia of Caves. USA: ElsevierAcademic Prress, 2005. p.406-408. 
STOEV, A.; STOYCHEV, T. Archaeoastronomical identification of the functional elements in rocky-cave sanctuary connected with ancient Cult toward the moon on Bulgarian land. Journal of caves and Karst Studies, v.54, n.1, p.1-6, June 1992.

SPIX, J.B.von; MARTIUS, C.F.P. von. Travels in Brazil in the years 1817-1820 undertaking by command of his Majesty the King of Bavaria. London: Longman, Hurst, Orme, Brown and Green, 1824. v.1.

SWEETING, M. M. Karst landforms. London: Mackmillan, 1972.

TATE, K. Sacred Places of Goddess: 108 destinations. San Francisco: Consortium of Collective Consciousness, 2006.

TRAVASSOS, L.E.P.; KOHLER, H.C.; KRANJC, A. The $6^{\text {th }}$ SINAGEO and the insertion of the Karst Geomorphology Thematic Session. Acta Carsológica, Ljubljana, v.35, n.2, p.170-171, 2006.

TRAVASSOS, L.E.P. ; GÓIS, A.J. ; GUIMARÃES, R.L. ; VARELA, I.D. . A Gruta de São Cosme e Damião e a Umbanda, Cordisburgo, Minas Gerais. Pesquisas em Turismo e Paisagens Cársticas, v. 1, n.2, p. 165-172, 2008.

TRAVASSOS, L.E.P.; TRAVASSOS, E.G.; TRAVASSOS, L.P.; TRAVASSOS, L.C.P. Non-specialists perception about endokarst and exokarst scenarios: visions from high school students. Acta Carsologica, Ljubljana, v.36, n.2, p.329335, 2007.

TRAVASSOS, L.E.P.; TRAVASSOS, E.G.; TRAVASSOS, L.P.; TRAVASSOS, L.C.P. Ensaio Exploratório sobre a percepção do endocarste e do exocarste de alunos do ensino médio como subsídio à Educação Ambiental. In: Seminário Cláudio Peres de Prática de Ensino e Geografia Aplicada, 4, 2006, Belo Horizonte. Caderno de Geografia. Belo Horizonte: PUC Minas, 2006. v.16. 1 CD-ROM.

TRAVASSOS, L.E.P.; VARELA, I.D. O uso religioso de uma caverna marinha: o caso da Gruta de Nossa Senhora de Lourdes em Saquarema, RJ. In: CONGRESSO BRASILEIRO DE ESPELEOLOGIA, 30, 2009. Montes Claros. Anais... Montes Claros:SBE, 2009

TRAVASSOS, L.E.P.; VARELA, I.D. Speleothems and their historical sacred calues: to examples from the State of Minas Gerais, Brazil. In: INTERNATIONAL KARSOLOGICAL SCHOOL, KARST SEDIMENTS, 16, 2008, Postojna. Short Scientific Papers. Postojna/Ljubljana: ZRC-SAZU. p.1-5.

TRAVASSOS, L.E.P. A importância cultural do carste e das cavernas 2010. 372f. Tese (Doutorado) - Programa de Pós-graduação em Geografia Tratamento da Informação Espacial. Pontifícia Universidade Católica de Minas Gerais.

TRAVASSOS, L.E.P. O Abismo Šemonovo (Šemonovo Brezno) e seu uso no período pós-guera. In: Encontro Nacional da ANPEGE, 8, 2009, Curitiba. Anais... Curitiba: ANPEGE, 2009. 1 CD-Rom.

TRAVASSOS, L.E.P. Reflexões sobre as áreas cársticas e a disposição de resíduos. O Carste, Belo Horizonte, v. 19, n.1, p. 9-20, 2007a. 
TRAVASSOS, L.E.P. Visões do relevo cárstico na mídia: literatura, filmes e notícias. Revista de Biologia e Ciências da Terra, Campina Grande, v.7, n.2, p.108-115, 2007b.

TRAVASSOS, L.E.P. Comentários sobre o Simpósio Internacional. Informativo SBE, v.1, n.93, p. 9-13, 2007c.

TRAVASSOS, L.E.P. Caracterização do carste da região de Cordisburgo, Minas Gerais. 2007d. 98f. Dissertação (Mestrado) - Programa de Pósgraduação em Geografia - Tratamento da Informação Espacial. Pontifícia Universidade Católica de Minas Gerais.

TUAN, Yi-Fu. Paisagens do medo (1979). São Paulo: Ed.Unesp, 2006. Tradução de Livia de Oliveira.

TUAN, Yi-Fu. Espaço e Lugar: A Perspectiva da Experiência (1977). São Paulo: Difel/Difusão Editorial, 1983. Tradução Lívia de Oliveira.

TUAN, Yi-Fu. Topofilia: Um Estudo da Percepção, Atitudes e Valores de Meio Ambiente (1974). São Paulo: Difel/Difusão Editorial, 1980. Tradução Lívia de Oliveira.

TURLEY, G. Humboldt's Gift: a geographer in profile. Mercartor's World, [s.d.], p.22-25, November/December 2001.

UNESCO. Global Geoparks Network: Guidelines and Criteria for National Geoparks seeking UNESCO assistance to join three Global Geoparks Network. Paris: UNESCO, 2007.

UNESCO. Operational Guidelines for the Implementation of the World Heritage Convention. Paris: UNESCO World Heritage Centre, 2008.

WILLIAMS, P.; FONG, Y.T. World Map of Carbonate Rock Outcrops v3.0. SGGES/University of Auckland: New Zealand, 11 Apr. 2008. Disponivel em: $<$ http://www.sges.auckland.ac.nz/sges_research/karst.shtm> Acesso em 20 Set 2008.

WILLIAMS, P. World Heritage Caves and Karst: A Thematic Study: A global review of karst World Heritage properties: present situation, future prospects and management requirements. Switzerland: IUCN, 2008.

ZHALOV, A.; STAMENOVA, M. A memory of the cave-sanctuaries in bulgaria (in memory of George Antonov. In: IV EUROPEAN SPELEOLOGICAL CONGRESS, Vercors, 2008, Lans-en-Vercors - Isère. Proceedings... Lans-enVercors - Isère: French Federation of Speleology/Speleological Federation of the European Union, 2008. p.229-232. 